


\title{
Cartografías de migración y desarraigo: percepciones de una casa fantasma a través de la expresión artística*
}

\author{
CARTOGRAPHIES OF MIGRATION AND UPROOTING: PERCEPTIONS OF A \\ HAUNTED HOUSE THROUGH THE ARTISTIC EXPRESSION
}

CARTOGRAFIAS DE MIGRAÇÃO E DESENRAIZAMENTO: PERCEPÇÕES DE UMA CASA FANTASMA ATRAVÉS DA EXPRESSÃO ARTÍSTICA

\section{Estefany Alfaro Buitrago**}

Cuadernos de Música, Artes Visuales y Artes Escénicas

/ Volumen 12 - Número 2 / Julio - Diciembre de 2017

/ ISSN 1794-6670/ Bogotá, D.C., Colombia / pp. 99-124

Fecha de recepción: 30 de enero de 2017

Fecha de aceptación: 31 de mayo de 2017

Disponible en línea: 28 de agosto de 2017

doi:10.11144/Javeriana.mavae12-2.cdmd

\footnotetext{
* Este artículo es producto del proyecto de investigación Cartografías de migración y desarraigo, desarrollado a partir de la beca de investigación Jóvenes Investigadores e Innovadores 2015 de Colciencias (adelantado entre mayo de 2016 y mayo de 2017). Dicho proyecto se ha desarrollado dentro del Semillero de Investigación Especies de Espacios, adscrito al Grupo de Investigación Pedagogía, Tecnología y Sociedad en las Artes Visuales, del Departamento de Artes Visuales de la Pontificia Universidad Javeriana de Bogotá.

* Maestra en Artes Visuales con énfasis plástico por la Pontificia Universidad Javeriana de Bogotá. Actualmente es joven investigadora de Colciencias y del Semillero de Investigación Especies de Espacios, Departamento de Artes Visuales, Pontificia Universidad Javeriana de Bogotá.
} 


\section{Resumen}

Este artículo es producto de un proyecto de investigación-creación, que tuvo como propósito la indagación sobre la construcción de la noción de hogar partiendo de la experiencia vivida por mi familia materna en la vereda de Santa Helena y el municipio de Anzoátegui en el Tolima, en el periodo conocido como la Violencia. La investigación tuvo como eje central las memorias familiares, testimonios que daban cuenta de las consecuencias que conllevaba el abandono del territorio a causa de la guerra, entre ellas, la pérdida del arraigo. A partir de una serie de entrevistas, se buscó definir los conceptos de desarraigo, hogary territorio para llevar a cabo una exploración plástica que se planteó como un proceso de pensamiento que permitió entender cómo se daba la configuración del hogar en medio de la guerra, las tensiones existentes en las dinámicas de formación de los límites del territorio y el desarraigo consecuencia de la imposibilidad de mantener esos límites. Para ello, se realizaron modelos a escala (dioramas) de las casas que habían sido habitadas por mi familia en Santa Helena, Lisboa e Ibagué. Contaron con disposiciones formales como la presencia de luz y sombras y algunos vacíos que volvieron tangible la relación de mi familia con dichos espacios. Unos funcionaban como una suerte de refugio, otros como espacios de juego e imaginación y otros como lugares cotidianos de convivencia, por ejemplo la cocina y el comedor

Palabras claves: construcción de hogar; cotidianidad; territorio; casa onírica; desarraigo

\section{Abstract}

This article is the product of a research-creation project and its purpose is to investigate the construction of the notion of home based on the experience of my maternal family in the village of Santa Helena and the municipality of Anzoátegui in Tolima, in the period known as la Violencia. The primary focus of this investigation was my family experiences, testimonies, which revealed the consequences of the abandonment of the territory due to the war, including the loss of roots. A range of interviews are sought to define the concepts of uprooting, the home and the territory to carry out a plastic exploration that allowed to understand how the home setting was done in the middle of war, the existing tensions in the dynamics of foundation of the limits of the territory, and the uprooting resulting from the impossibility of maintaining these boundaries. To do so, scale models were made of houses that were inhabited by my family in Santa Helena, Lisboa and Ibagué. They had formal provisions such as the presence of light and shadows and some gaps that made my family's relationship with spaces tangible. Some of those places worked as a sort of shelter, others as play and imagination spaces and others as common areas of coexistence, for example, the kitchen and the dining room

Keywords: home setting; routine; territory; house oneiric; uprooting

\section{Resumo}

Este artigo é resultado de um projeto de pesquisa-criação, que teve como objetivo a indagação pela construção da noção de lar desde a experiência da minha família materna na aldeia de Santa Helena e no município de Anzoátegui em Tolima, no periodo conhecido como la Violencia. A pesquisa teve como eixo central as memórias familiares, testemunhos, que perceberam as consequências que implicou o abandono do território por causa da guerra, incluindo a perda das raízes. A partir de uma serie de entrevistas buscou-se definir os conceitos de desenraizamento, lar e território para desenvolver uma exploração plástica le vantada como processo de pensamento que permitiu entender como foi dada a estrutura do lar no meio da guerra, as tensões existentes nas dinâmicas da criação dos limites do território e o desenraizamento como consequência da impossibilidade de manter esses limites. Para esse fim foram feitos modelos das casas que tinham sido habitadas por minha família em Santa Helena, Lisboa e Ibagué. Contaram com disposições formais como a iluminação, as sombras e alguns vazios que tornaram tangível a relação da minha família com esses espaços. Alguns funcionavam como uma espécie de refúgio, outros como espaços de jogo e imaginação e outros como locais cotidianos de convivência, tais como cozinha e sala de jantar.

Palavras chave: arte marginal; construção do lar; cotidianidade; território; casa onírica e desenraizamento 
Ya no vive nadie en ella

y a la orilla del camino silenciosa está la casa se diría que sus puertas se cerraron para siempre se cerraron para siempre sus ventanas Jorge Molina Cano (canción Las Acacias)

La sombra de la guerra ha sido una constante del contexto colombiano. La cotidianidad de la población en distintas regiones del país ha estado marcada por la violencia. Este artículo es producto de un proyecto de investigación-creación que tiene como objetivo indagar sobre las prácticas cotidianas de mi familia materna, en la vereda de Santa Helena, municipio de Anzoátegui en el Tolima, en el periodo denominado, y reconocido en el imaginario popular, la Violencia. En el ámbito de lo doméstico, en las acciones del diario vivir dentro de la región, es importante la relación de la casa con el territorio: cómo se construye un hogar, cómo se mantiene el hogar en medio de la guerra y cómo se manifiesta el sentimiento de desarraigo por la ruptura del primer hogar a causa de la violencia política. El propósito de este estudio es indagar sobre cómo a través del arte se pueden evidenciar prácticas de resistencia, ligadas a memorias familiares, que constituyen formas de mantener vivo el sentimiento de protección que proviene de la primera casa, aun cuando se esté lejos del territorio. Esto se realizará por medio de exploraciones plásticas, a partir de la recopilación de relatos de itinerarios sobre las sucesivas migraciones vividas por mi familia, derivadas de épocas de transición violenta en Colombia.

Los testimonios que dan cuenta de esos trayectos, y el impacto que tuvo para la familia tener que dejar su casa y su tierra, parten de entrevistas realizadas a mis tías maternas Marisol, Gloria y Amanda entre 2014 y 2016. Además de estos relatos, dentro de la investigación, se incluyen fragmentos de un escrito realizado por mi abuela materna Amalia en 2011 sobre lo que fue su vida en la región del Tolima y de algunos de los hechos violentos que presenció.

El inicio de esas migraciones tiene origen en Santa Helena, una pequeña vereda de filiación conservadora —en su mayoría- del municipio de Anzoátegui (ubicado al norte del departamento del Tolima). A comienzos de 1940, vivían en esta región, en la finca El corazón, mis abuelos María Amalia Buitrago de Alfaro y Rudensindo Alfaro Lombana. Allí nacieron sus nueve hijos: Marisol, José Yesid, Gloria Teresa, Amanda, Guillermo León, Óscar, José de Jesús, Luz Stella y Martha Carmenza. En la finca tenían su casa, sus animales, una pequeña tienda de abarrotes y algunos cultivos. Aquella casa había sido construida con esfuerzo y con el anhelo de forjar un espacio seguro para la familia; era un entorno apacible sin mayores sobresaltos. Repentinamente, llegó la guerra y la vida en Santa Helena no volvió a ser la misma. Esto produjo la transformación de las dinámicas habituales de la familia y del sentimiento de protección que les brindaba el hogar. Tales acontecimientos hicieron que Gloria y Marisol —las hermanas mayores - fueran enviadas a estudiar a Lisboa, un corregimiento aledaño. Con el tiempo, la situación se hizo insostenible frente a la incertidumbre de la guerra, y la familia decidió marcharse de Santa Helena. Así emprendieron el camino hacia lbagué y posteriormente a Anzoátegui, donde la violencia se recrudeció; y aquello que había quedado atrás como una sombra regresaba con más fuerza y dejaba a su paso un sinnúmero de muertos. 
Según la historiografía oficial, el periodo conocido como la Violencia abarcó 1948-1964 y fue detonada por el Bogotazo, insurrección popular producto del asesinato del político liberal Jorge Eliécer Gaitán el 9 de abril de 1948. Esta insurrección en la capital del país impactó con fuerza en las zonas rurales, donde se desataron brotes de violencia. Entre las manifestaciones de este fenómeno, estaban la quema de parcelas, el hurto de ganado y café, las masacres ejecutadas contra la población por bandoleros conservadores y liberales, por la policía del Gobierno conservador llamada chulavita (provenientes de Boyacá) y por Los Pájaros (mercenarios de terratenientes conservadores originarios del Valle del Cauca). Estos hechos se presentaron constantemente en los municipios al occidente del Tolima dedicados a la siembra de café (Uribe 1990, 27). En el Tolima, se intensificaron este tipo de prácticas, pasando del puesto décimo en 1949 al primero, en años posteriores, entre los departamentos más violentos del país. Las masacres de la población civil se volvieron recurrentes hasta comienzos de la década de 1960 (53).

Es en este contexto en que mi familia se trasladó de Santa Helena a Anzoátegui en el periodo que abarcó los últimos años de la década de 1950 y los inicios de la de 1960. Fue una época marcada por la incertidumbre, la perplejidad y el miedo ante las continuas acciones violentas contra la población civil. En una de las conversaciones con mi tía Gloria, la angustia estaba implícita en su relato al recordar los sucesos de esos años:

Yo duré muchos años que no comía carne porque relacionaba mucho la carne con ver tanta masacre. Porque a la gente no la mataban con balas sino a machete; es decir, con arma blanca. No les echaban bala, que se murió, que le pegaron un tiro ni nada, sino que los degollaban, les quitaban la cabeza. Le decían corte de franela en ese tiempo. (entrevista con la tía Gloria, 15 de enero de 2014)

Este tratamiento macabro al cuerpo de las víctimas propició la práctica de una serie de cortes, entre los que se encontraban: corte de oreja (para contabilizar muertos), corte de florero (mutilación de brazos y piernas que se reubicaban en la zona de la cabeza), corte de corbata (por la garganta se sacaba la lengua a partir de una perforación), destripamiento, decapitación (manera de rematar a la víctima), corte de mica (después de decapitar a la persona se ubicaba la cabeza en la zona del pubis); y corte de pechos (Uribe 1990, 173-175). Estas acciones generaron una relación cotidiana con la muerte, que se percibe con claridad en el relato de Gloria, en los recuerdos que conserva de esa época: "No pasaba un solo día que no repicaran las campanas para enterrar muertos, y a veces entierros colectivos de diez, quince personas [...] Entonces el diario vivir en Anzoátegui era estar conviviendo con los muertos todos los días". El sonido de las campanas era lo que más recordaba, porque era el anuncio de la llegada de la tragedia. La impotencia y el terror eran sentimientos constantes ante la imposibilidad de transformar el contexto en el que vivían.

La forma en la que se llevaron a cabo las masacres tenía un carácter ritual presente en la serie de acciones ejecutadas por las cuadrillas de bandoleros. El móvil de estos actos era de origen diverso; podía ser por retaliaciones, acciones fortuitas o por divergencias políticas fruto del bipartidismo que había generado una fuerte polarización en los espacios rurales. El propósito de estas acciones era generar, por medio del terror, la preeminencia partidista en las regiones donde se daba igualdad de miembros de los partidos Liberal y Conservador. El momento 
inicial de las masacres estaba mediado por intimidación y advertencias de muerte. Luego, se procedía a ingresar a las casas para cometer los crímenes donde se podían dar o no actos de tortura antes de la ejecución. En esta fase, los victimarios cometían diversas vejaciones contra sus víctimas para generar una distancia con ellas. Después del asesinato, se realizaban cortes y manipulación de los cuerpos para rematarlos. Por último, se dejaban notas firmadas por los autores de la barbarie en el lugar de los hechos (Uribe 2004, 85-92).

Estas formas de intimidación en las cuales, primero, se notificaba a la víctima de su muerte inminente me remiten a un fragmento de los escritos de mi abuela Amalia. Allí narraba cómo se evitó que la policía chulavita matara a una mujer liberal de Santa Helena que refleja los vínculos de solidaridad y comunidad en medio de la guerra. Los chulavitas habían llegado a la tienda de abarrotes de mi abuela en Santa Helena, anunciando la orden que tenían de matar a la señora liberal. Mi abuela, pese a saber dónde vivía la mujer, guardó silencio y afirmó no conocerla. En su relato, describe los acontecimientos posteriores: "Como mi hijo Yesid iba a llevar la sal para el ganado a la finca La Alcancía, pasando por la finca de esa señora, yo le envié una notica dentro de la sal, que decía: '¡Escóndase que la van a matar!'.' Es una situación compleja que constata el grado de indefensión en el que se encontraba la población en aquel periodo, y la necesidad de crear mecanismos dentro de la misma comunidad para resguardar la vida.

En medio de ese contexto álgido, crecieron mis tíos y mi mamá. Experimentaron por primera vez la noción de hogar, la forma de habitar el espacio y el arraigo al terruño. El filósofo Martin Heidegger (2001, 128-129) afirma que el significado de habitar comprende en sí mismo el concepto de construir. Para ello, indaga sobre el origen de la palabra construir en su idioma natal (el alemán) y encuentra que está ligada tanto a las nociones de edificar espacios arquitectónicos como a proteger y cuidar el crecimiento. Es decir, habitar no se limita a residir en un alojamiento, sino que implica resguardar su existencia y desarrollo. Esta reflexión aborda un punto fundamental en mi investigación para comprender cómo mi familia habitó el territorio de Santa Helena y la ruptura que se originó por el proceso de migración que vivió. Mis abuelos construyeron con sus propias manos su casa, cultivaron la tierra, criaron animales y, gracias a esto, alimentaron a sus hijos hasta que llegó la guerra que generó la ruptura. Esto es visible en las conversaciones que sostuve con mis tías Gloria, Marisol y Amanda, en las que definieron la palabra hogar desde el lenguaje cotidiano según sus propias experiencias.

Amanda comprende el hogar desde el lugar "donde tiene trabajo, comida, su casa, donde descansar, y en eso se le va la vida. Eso es el hogar, no es más. Donde uno pueda producir y vivir." Marisol siente que las raíces del hogar "se van construyendo por el afecto que hay entre la familia. La forma en que el papá y la mamá dan cariño y recibe uno también cariño." Resalta la importancia de las personas que conforman ese hogar y posteriormente menciona que "allá en Santa Helena estaba la casa, estábamos todos, en un sitio y mamá había construido la casa, porque ahí habían ido naciendo todos los hijos." Gloria afirma:

Esta es mi casa, porque fue algo que yo elaboré prácticamente con mis propias manos. Es una masa de barro que yo la fui amasando, la fui modelando, hasta que fabriqué eso. Entonces, estando en ese cuadro de tierra formé, hice mi casa y pude ubicar ahí a mi familia. Eso me permite llamarla mi casa, porque yo la hice con mis manos, con el esfuerzo de mi cuerpo, con el trabajo que devengué. Cambié mis energías por el dinero, para poder vivir, para tener una familia y para tenerla bien. (entrevista con la tía Gloria, 17 de febrero de 2016) 
Estas concepciones acerca del hogar presentan ciertas diferencias. Amanda centra el significado de esta palabra en las acciones de trabajar y vivir. Marisol señala la preponderancia de las relaciones de afecto que se conforman en este espacio. Finalmente, Gloria se acerca más a la idea de habitar como construir. Para ella, el hogar implica edificar con las propias manos la casa tanto real como simbólicamente. El cuidado parte de organizar y seleccionar los objetos que van a habitar el espacio, pero también de cuidar y proteger la familia. Es una relación entre los seres que habitan ese espacio y la casa misma como objeto. Estas percepciones parten de la experiencia del primer hogar en Santa Helena, el cual determinó sus relaciones posteriores con otras casas.

Bachelard $(1997,45,47)$ refiere, a partir de su análisis fenomenológico que, a través de la experiencia de habitar la casa primigenia, esta deja su huella en nuestro cuerpo, inscribe en nosotros unas costumbres que, pese al tiempo, no desaparecen, sino que se convierten en punto de referencia y guía para las futuras casas que habitamos. Las medidas y distancias de este lugar siguen intactas en nuestros recuerdos y albergan en su interior los sueños y ensueños. Es la alusión a la casa onírica, aquella que va más allá del recuerdo y la simple descripción física, para ser evocada a partir de cómo soñamos esa casa de la infancia cuando vivimos en ella: la forma como edificábamos muros imaginarios que transmitían protección y se convertían en una fortaleza, los espacios en los que sentíamos la soledad o el aburrimiento y los rincones que guardaban nuestros secretos.

Para poder vislumbrar cuál había sido la casa onírica de mi familia, la verdadera intimidad de ese espacio, era necesario recurrir a la oralidad y a las ensoñaciones. En las entrevistas con Gloria, Amanda y Marisol, por momentos las alusiones a la casa de Santa Helena eran muy precisas, pero en ocasiones surgían detalles contradictorios que entre ellas mismas iban resolviendo. El calor de hogar y la sensación de percibir ese espacio como propio era identificado por ellas en tres lugares: la cocina, el comedor y el espacio de costura. Para Amanda, la cocina era el detonante de los sueños, la posibilidad de conocer lugares que nunca antes había visto. En las noches, los niños de la casa se hacían alrededor de la estufa de leña esperando escuchar las historias de Timbillas. Él era un trabajador de la finca El Corazón, que les narraba historias de las Mil y una noches, de William Shakespeare, de piratas, forajidos y del mar. La descripción del mar es lo que más recuerda Amanda, ya que para ese entonces los paisajes que estaban inscritos en su memoria eran solo los de Santa Helena. No conocía el mar, la primera vez que lo hizo fue a través de las palabras de aquel hombre que tenía gran habilidad para contar historias. La estufa dejaba por un momento de ser el objeto donde se cocinaban los alimentos para convertirse en el lugar en el que convergía la curiosidad propia de la infancia.

El símbolo del hogar para Gloria y Marisol era el comedor, el espacio donde la familia se reunía. Marisol consideraba que en este lugar todos los que vivían en la casa contaban los pormenores del día. Para Gloria, la calidez de la casa iniciaba en el estar junto a sus padres, en la sensación de seguridad y protección que le brindaban (junto a ellos el miedo se disipaba). De modo similar, el comedor le transmitía un sentimiento cálido, evidente en una de nuestras conversaciones donde mencionaba que "el acto de comer, de estar reunidos ahí, da como calor de hogar, como vida. Uno en el comedor comparte tantas cosas, todo lo que usted quiera hablar, lo habla en el comedor". Para Gloria, el espacio donde se comparte la comida tiene vitalidad, allí confluyen las preocupaciones, los planes y la cotidianidad en su expresión más simple. En la finca, Gloria se sentaba en uno de los taburetes del comedor, 
frente a la mesa grande de madera a escuchar con gran interés a las mujeres que iban a visitar la casa. Y otras veces se quedaba viendo a Amalia cómo cortaba sus telas con dedicación y precisión para los encargos que le hacían.

El acto de coser tenía una connotación particular para Amanda y hoy mantiene una relación directa con el recuerdo de aprender a escribir. Ella mencionaba que a la edad de aproximadamente 5 o 6 años solía hacer planas en su cuaderno a rayas. “En la finca mamá nos enseñó al lado de ella, nos sentaba en un taburete ella cosiendo y ella nos iba tomando la lección en un cuaderno". En su recuerdo, se percibe alegría al mencionar cuando Amalia revisaba las frases que iba armando. Primero, le dictaba una consonante que debía unir con cada una de las vocales y, después, debía armar una frase. Una de esas frases era "mi mamá me ama", la cual repetía a manera de plana. Así fue que Amanda aprendió a escribir pasando varias horas junto Amalia. La máquina de coser estaba ubicada en un pasillo al lado del comedor. Amalia cosía allí con la luz de la mañana, la mesa de corte era la del comedor y en las noches ubicaba la máquina de coser en la sala donde cosía a la luz de una vela. Era el espacio en el que se construían vínculos de cuidado, protección, afecto y aprendizaje. A través de estos testimonios, se puede dimensionar cómo se daba la apropiación de un espacio y la carga emocional que se transfería a este cuando proveía refugio. No es la configuración de cualquier espacio, es la morada, el lugar que alberga nuestros anhelos y temores.

\section{ENTRE TERRITORIALIZACIÓN, DESTERRITORIALIZACIÓN Y DESARRAIGO: EL ABANDONO DE SANTA HELENA}

Según Deleuze y Guattari $(2004,318,320)$, el acto de territorializar, de configurar un territorio, parte de una especie de cadencia o sonoridad organizativa (espacio-temporal) que lo dota de coherencia expresiva, llamado por estos ritornelo. En este acto, se hacen consistentes tres características fundamentales para conformar el territorio: las fuerzas del caos, las fuerzas terrestres y las fuerzas cósmicas. Las fuerzas del caos se relacionan con la fijación momentánea de un punto frágil en medio del caos como principio de orden; las fuerzas terrestres se producen cuando ese centro frágil se transforma en casa por medio del orden de un espacio concreto, allí se mantiene en el exterior el caos que filtra ciertos elementos de este; y las fuerzas cósmicas son la apertura, en ese espacio limitado, de salidas hacia las fuerzas del caos. El carácter sonoro del ritornelo se configura a partir de medios heterogéneos que existen por la repetición periódica que produce códigos. En esas repeticiones, para que exista ritmo, se deben dar variaciones que, a través de contrapuntos, permiten el paso de un medio a otro (un código a otro), conocido como transcodificación. Y esos medios devienen materias expresivas que trazan un territorio. Un ejemplo de esto es la delimitación que hacen los pájaros del territorio por medio de sus cantos. 
Pensar el predominio sonoro del ritornelo me remite al sonido del cuerno que se escuchaba en Santa Helena como señal de alarma, de huida. Amanda tiene muy presentes estos acontecimientos:

Recuerdo los días difíciles cuando la chusma nos perseguía en la finca de Santa Helena, del municipio de Anzoátegui. Si algún vecino nos avisaba por medio del toque o silbido del cacho, eso nos indicaba que saliéramos de las viviendas y buscáramos un refugio seguro, que eran las cuevas o túneles que habían en la finca muy cercana a la quebrada o río. Porque el río o la quebrada era el medio de escape seguro sin dejar huella, era el camino que debíamos tomar al momento de escapar y protegernos. Así que cogíamos río arriba o río abajo por la orilla hasta perdernos por la maleza. Esto se hacía para no dejar la huella del zapato, del pie desnudo o de una alpargata, y pasábamos así la noche debajo de las piedras más grandes que nos protegían, o cuevas que se formaban al paso del río, o por el cauce del río. Al aparecer la mañana salía una sola persona del escondite, inspeccionaba el terreno desde muy lejos y luego se aproximaba sigilosamente hasta la casa, y si todo está bien, que no había nada extraño, que no habían quemado la vivienda, regresábamos a reiniciar el día normalmente. (entrevista con la tía Amanda, 9 de diciembre de 2014)

En aquella época, se usaba un cacho de vaca al que se le hacía una incisión en su extremo superior para que funcionara como un dispositivo que amplificaba el sonido y permitía que todas las personas de la vereda pudieran escucharlo. A partir del cacho, se creaban contrapuntos (fundamento del ritornelo), que hicieron emerger un código entre los habitantes de Santa Helena, quienes sabían que su sonido anunciaba que la vereda sería atacada por la chusma (expresión usada por los conservadores para referirse a los bandoleros liberales). A partir del código de alarma, se trazaban los límites del territorio por transcodificación:

Primer medio, advertencia del peligro: el vigía desde la montaña identificaba la llegada de la chusma a la vereda, hacía sonar el cacho.

Segundo medio, ruptura de la tranquilidad: los pobladores, al escuchar el cuerno, iniciaban la huida, pasaban de sus casas al monte.

Tercer medio, acciones de huida: seguían la ruta del río para esconder las huellas de los zapatos y evitar ser encontrados.

Cuarto medio, búsqueda de refugio: se iban del río a los socavones para ocultarse en la oscuridad.

Quinto medio, retorno a los espacios familiares: finalmente con el paso de la noche al día salían de este lugar para retornar a la cotidianidad.

Con esta práctica, se daba un uso distinto del que tenía el cuerno en tiempos de tranquilidad. Si bien antes de las incursiones violentas en Santa Helena era utilizado para llamar a los jornaleros a la hora del almuerzo, la transformación obedeció a la necesidad de la población de encontrar mecanismos prácticos de protección. Como respuesta no violenta al estado de crisis, se partía de un trabajo de producción simbólica que evidenciaba la emergencia de vínculos colectivos de solidaridad. 
Al estar constantemente ante la amenaza de que el caos franqueara ese espacio de protección, la familia debía abandonar la casa y crear centros momentáneos de resguardo. Esos centros tenían como punto de partida el espacio-temporal sonoro del cuerno, que proveía la franja de huida; el siguiente espacio era el camino hacia el monte; luego el río (que borraba cualquier rastro de sus pasos); y, por último, los socavones (donde se ocultaban del peligro, hasta que podían regresar a las casas). En este orden de ideas, el territorio debía expandir y contraer sus límites para poder preservarse. El relato de Amanda señala un aspecto importante que permite dilucidar las tensiones existentes en la formación de un hogar en medio de la guerra. La casa de Santa Helena era un territorio que albergaba prácticas de cuidado y protección de la familia, pero fuera de los límites o las membranas de ese territorio se encontraba el caos materializado en la guerra.

Era patente que la casa de Santa Helena debía producir aperturas a las fuerzas del caos para mantenerse. En el acto de territorializar, están presentes también las fuerzas de desterritorialización, que resultan necesarias para mantener el territorio (Deleuze y Guattari 1994, 331). La familia debía desplazarse momentáneamente para continuar en el territorio como única forma de seguir con vida sino se quería abandonar para siempre el lugar donde habían formado un hogar. Siempre existía la esperanza de retornar, de reterritorializar para volver a las dinámicas cotidianas donde la vida seguía su curso. No obstante, el acto de desterritorialización no se relacionaba específicamente con aspectos negativos, como la guerra, sino que estaba presente en otras situaciones: los abuelos dejaban la casa momentáneamente para sembrar la tierra y obtener alimentos; la familia se desplazaba hasta Anzoátegui los sábados para abastecer la tienda de abarrotes que tenían en la finca; mis tíos iban a estudiar a la escuela todas las semanas. Mi familia vivió constantemente aquellos movimientos de territorialización y desterritorialización, hasta que un día se extinguió la esperanza de volver a construir territorio. En ese momento, habitar Santa Helena se volvió imposible porque dejaron de haber garantías para seguir viviendo tranquilamente. Esa fuerza positiva que permitía mantener el arraigo, el vínculo con la casa, con la tierra y los afectos construidos en ella, había desaparecido. De esa imposibilidad, del individuo que se queda sin territorio, nace el desarraigo.

Yo pienso que fue por ahí en 1957, si no estoy mal, cuando nos tocó abandonar la finca donde habíamos vivido toda la vida. Nosotros éramos niños, pero mi papá y mi mamá habían conseguido todo eso con esfuerzo. Tenían su buena casa, su finca, teníamos hartísimos animales, hasta yo tenía mis propiedades. Yo tenía 10 años por mucho. Yo tenía una gallinita que me había dado huevos, tenía cerdos, tenía buena cría, y todo eso. Cada uno teníamos como un pequeño capital.

Pero ya se llegó la situación que era tan álgida, como se dice, que ya era imposible convivir allá. Entonces, tocó levantar toldo como el cuento y nos fuimos para Ibagué. El día que nos fuimos en todo el camino, por todo el camino rial, todas las casas que encontrábamos eran ardiendo, quemadas. Y no se encontraba un alma, y es un trayecto muy lejos, de un día completo desde la finca hasta San Bernardo. Eso fue muy triste porque era como si estuviéramos en guerra, estábamos en guerra prácticamente.

Entonces, todas las casitas donde uno antes pasaba y veía a la gente contenta o barriendo, que salía a vender cositas al camino y eso, ya nada, todo era en ruinas. Las casas no estaban quemadas, eran ardiendo. Mamá había aprovechado para el camino hacer aprontes, o llevar para 
comer, pero el agua teníamos que consumirla de las quebraditas, llegábamos y tomábamos agua. Fue una situación muy dolorosa y muy triste, supremamente triste porque a nosotros nos habían arrancado de allá, lo que teníamos. Es como un desprendimiento, un desarraigo total, porque desde ese día nunca volvimos, yo por lo menos nunca volví a la finca, no sé cómo quedaría ni nada. (entrevista con la tía Gloria, 15 de enero de 2014)

El año de 1957 tiene una recordación especial para mis tías, porque fue el momento en que la familia se separó, en que las dinámicas cotidianas se transformaron y se generó un distanciamiento con las personas y las cosas que les proveían seguridad. Sin embargo, el abandono definitivo de Santa Helena no lo hizo al mismo tiempo toda la familia. En principio, se marcharon a Ibagué Amanda, Gloria, Marisol y Stella, pero Amanda solo vivió allí por un año mientras cursó segundo de primaria. Alrededor de 1960 la familia que aún permanecía en Santa Helena se marchó definitivamente para comenzar una nueva vida en Anzoátegui junto a los que habían partido anteriormente. Amanda recuerda claramente cómo fue la partida de Santa Helena:

\begin{abstract}
Nosotros nos fuimos pero no sabíamos que no íbamos a volver, sin saber. [...] apenas amaneció ya teníamos las bestias, caballos todo lo que se tenía, y con la ropa que uno tuviera puesta. Íbamos a caballo los muchachos, mamá iba en su caballo y llevaba a Carmenza en los brazos, creo. Y los demás montábamos de a dos o de a tres. Nos fuimos y llegamos allá como cuando uno se mete en una nube blanca, no se veía pueblo. Porque papá sabía adonde llegar. Y llegar a esa nube. Oscuro, oscuro. Así duraron días y días, uno no veía nada. Con lo poco que se llevaba, papá buscó algo de comida y con las ollitas, pues se hizo lo poco que se podía. [...] La casa me pareció terrible porque uno encima de otro, uno encima de otro, imagínese. Pasarse uno a dos piecitas y el sótano donde se pudo medio organizar para los hombres y las mujeres en esa piecita tan chiquitica. Lo único que sí se echó adelante fueron las dos máquinas de coser y con esas nos bandeamos ahí en Anzoátegui. Desde que llegamos a coser y a coser. (entrevista con tía Amanda, 6 de octubre de 2016)
\end{abstract}

Mi familia tuvo que reconstruir su hogar en un nuevo territorio sopesando las situaciones adversas que se le presentaban. El proceso de migración que ellos vivieron tuvo como consecuencia el desarraigo, sentimiento descrito en los testimonios de Amanda y Gloria acerca del día en el que se marcharon de Santa Helena. Desde los lazos familiares fragmentados debieron modelar y cargar de sentido ese espacio que sería su casa, intentando recuperar el arraigo en presencia de la guerra. Las condiciones de Santa Helena y Anzoátegui eran distintas, en Santa Helena escapaban hacia el monte para esconderse y en Anzoátegui debían usar el sótano como refugio. Ya no tenían la huerta para sembrar, no estaban los cultivos de café, no estaban los árboles que los proveían de frutas; ya no se tenía al alcance de la mano la abundancia del territorio. Tal vez estaba presente de nuevo el sonido de un cuerno (las versiones de mis tías no coinciden en este punto), pero ya no existía el monte, el río ni los socavones en los que esconderse. Esa pesadumbre que transmite el relato de mi tía Amanda al describir la casa de Anzoátegui da cuenta de la pérdida a la que se enfrentaron. 
El panorama era complejo. Al pueblo llegaban frecuentemente, a lomo de mula, cantidad de muertos, existía el miedo constante de que pudieran entrar a atacarlo y, en ocasiones, se sentían atrapados. La ruta que conducía a lbagué no era segura y por los caminos solían haber tomas de bandoleros que perpetraban masacres y mataban a los que encontraran a su paso. Fue un periodo lleno de zozobra que debieron afrontar para continuar.

Ese reiniciar de sus vidas partía de una pérdida. El problema era cómo explicar esa pérdida, cómo describirla. Para hacer un acercamiento a las dimensiones que tuvo este hecho, fue necesario apelar a los testimonios de mis tías, a la pregunta por el desarraigo y sus consecuencias. Marisol lo define como "algo duro que uno siente, algo que se desprende de uno mismo. Se siente tristeza, como que uno ya no cree en nada". Sus palabras transmiten la pérdida de esperanza, de confianza en el porvenir: "Crece uno como sin ese apego a nada, le da lo mismo una cosa que otra. Yo crecí ya así, ya uno forma un hogar pero sin ese amor al terruño". Lo que les quitaron fue ese vínculo que constituía la tierra en un territorio que fuera posible legar a los hijos.

Para Amanda, el desarraigo se manifiesta como la imposibilidad de una acción de un anhelo. "Cuando uno no logra echar raíces, eso es desarraigo, ya en cualquier lugar del mundo puede vivir porque no va a tener nada que lo agarre, nada que lo motive. Antes, al contrario, cualquier cosa lo afecta". Su relato transmite la pérdida de un soporte vital que permitía el vínculo con la tierra, teniendo como consecuencia sentirse foránea constantemente, ya en ningún lugar encuentra elementos que la identifican. Lo que se extravió fue el sentimiento de identidad frente al territorio. Ese proceso de migración es para Amanda como "cuando le quitan a uno la piel"; es una imagen violenta, dolorosa, que transmite una pena profunda. Es sentirse vulnerable, carente de algo esencial. Esa imagen es simbólica pero a la vez real, ya que en la Violencia existían prácticas atroces contra el cuerpo, que dejaron heridas profundas en la memoria colectiva.

Uno de los artistas que ha trabajado acerca de este tema es Luis Ángel Rengifo con su serie Violencia (1964), imágenes de cuerpos monstruosos, dolientes y transgredidos que carecen de cualquier matiz cotidiano (Pini 1986, 13). Este es uno de los tantos testimonios que desde el campo del arte se han hecho sobre este periodo en nuestro país. Un grabado de la serie, que tiene elementos que se relacionan con el relato de Amanda, es Piel al sol (figura 1). Allí aparece la piel de una mujer estirada y anclada al piso con clavos, en un espacio rural

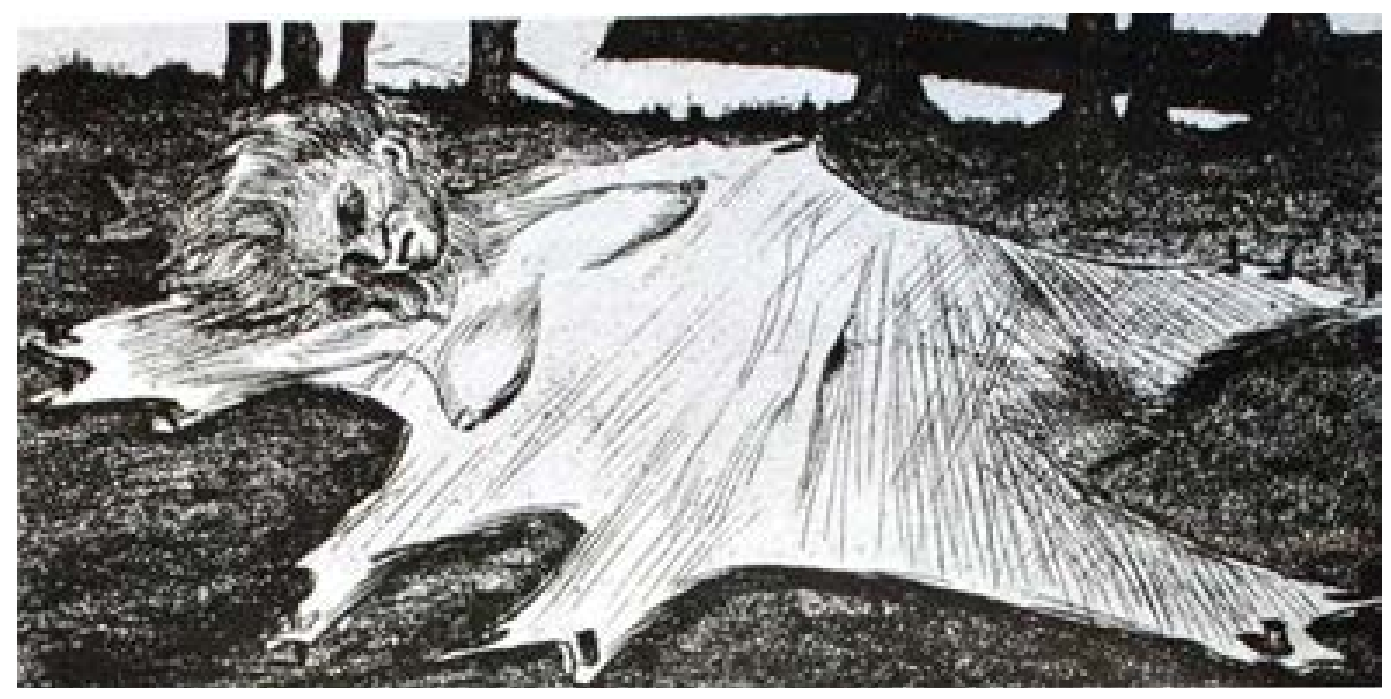

Luis Ángel Rengifo (1964): Piel al sol. Agua fuerte y aguatinta, 16×29cm. Colección Museo Nacional. 
que se intuye por el pasto y la cerca que se deja entrever al fondo. En esa imagen, se expone una visión de lo que fueron los estragos de la guerra a partir de la construcción de un paisaje desolador, sombrío y lúgubre. Esto puede interpretarse desde lo simbólico. Arrancar la piel es una práctica cruel y macabra en la guerra y también puede representar la pérdida del territorio; como lo dice Amanda, dejar Santa Helena fue para ella como "cuando le quitan a uno la piel."

Tanto los recursos técnicos de la aguatinta y el aguafuerte como la determinación de zonas de grises dramatizan en la obra de Rengifo, con altos contrastes de luz y sombra, las expresiones de sufrimiento en el cuerpo y rostro de la mujer y en el entorno paisajístico que desde lo expresivo manifiestan la pérdida de esperanza.

Gloria le daba el nombre de vacío al desprendimiento que genera el desarraigo: "Totalmente una ruptura, una ruptura completa porque deja un vacío que no lo llena nadie. Porque fue un hecho que estábamos todos tranquilos, y de pronto, se disparó algo que nadie estaba esperando, como un volcán". Es un quiebre que parte de acontecimientos repentinos, por lo que es muy difícil de sanar. La forma que ella encontraba para expresar las consecuencias de esta situación era la analogía de la familia con una hoja de papel rota en la cual, por más que se intentara reconstruir, siempre estarían presentes las marcas. Para mi tía Gloria, son profundas las consecuencias de la ruptura con Santa Helena, porque para ella el arraigo proviene del corazón, de cuidar y proteger el crecimiento de aquello que se ama, y por eso perderlo produce un gran dolor. Este acontecimiento lleva implícito el extravío del soporte o lugar en el que asir la existencia. No obstante, encontró en Anzoátegui la oportunidad de sanar y reconstruir ese calor de hogar que le habían arrancado:

Ya en Anzoátegui volvimos a tener ese calor de hogar porque ya teníamos la casa, era nuestra casa, porque era una casa que papá había comprado, que era de él. Estábamos en nuestra propiedad. Cuando uno está en una casa propia, no sé explicarle, pero es tan diferente, da tanta seguridad, y le da a uno tranquilidad. Saber que donde uno está es de uno, eso me da poder, como alegría, me da mucha satisfacción. La casa era de nosotros, entonces uno llegaba, ya estábamos con mamá ahí, entre todos compartíamos, mamá cocinaba, nosotras ayudábamos. Ella siempre nos enseñó a cocinar, a lavar, a planchar, a organizar la casa, a tener una casa muy bien arreglada. A querer lo que tenemos, la casa. (entrevista con la tía Gloria, 17 de febrero de 2016)

La posibilidad de conformar de nuevo un hogar en Anzoátegui y construir territorio, comprendiendo las dinámicas diferentes a las que se enfrentaba la familia, tenía como punto de partida la experiencia de Ibagué. Allí estuvieron presentes las relaciones de cuidado y amor que provenían de la tía Ema. Fue una segunda mamá: todos los días se preocupaba de su alimentación, su educación, de escucharlos, de que no se sintieran solos. Mi abuela Amalia, al no poder estar todos los días con sus hijos en lbagué, porque tenía que resolver las cosas con mi abuelo en la finca, los dejó al cuidado de Ema en busca de la tranquilidad y el bienestar de ellos. Hay una fotografía que muestra ese cuidado por parte de ella (figura 2), donde está sosteniendo en sus brazos a mi mamá Stella en el balcón de la casa. Ema representaba en esa época el hogar que mis tías y mi mamá habían perdido, mantenía vivo el calor de casa y evitaba que lo olvidaran. De esta forma, en ocasiones, el cuerpo se convierte en territorio para resguardar y proteger. 


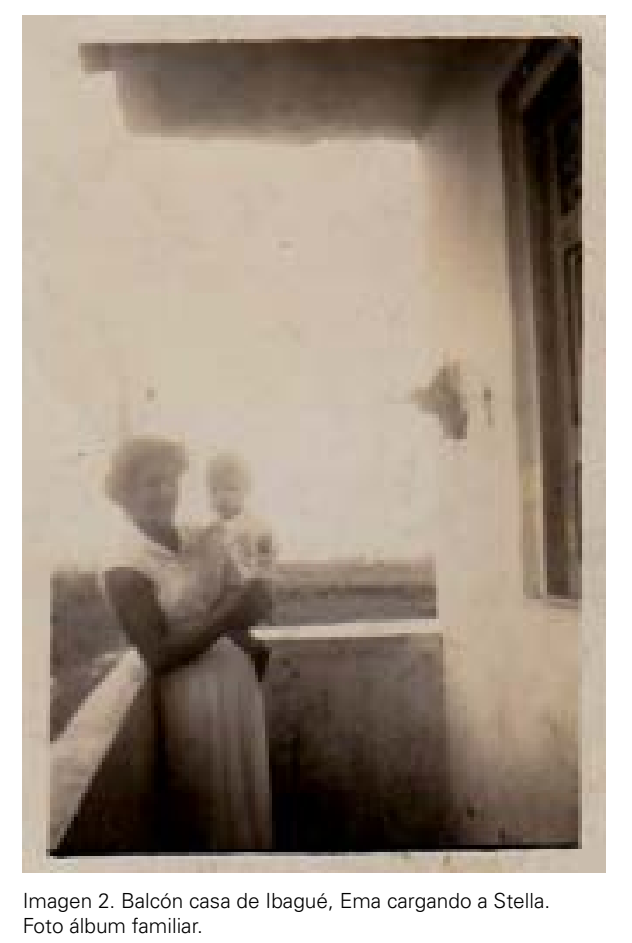

La historia de migración de mi familia comparte aspectos planteados en la novela LoS ejércitos, de Evelio Rosero, en la cual se describen la pérdida del territorio, la incertidumbre frente a la guerra, el desplazamiento y el sentimiento de desarraigo. La historia se desarrolla en el pueblo de San José, donde vive el profesor Ismael y su esposa Otilia. La vida transcurre apaciblemente de forma rutinaria, hasta que intempestivamente llega la guerra. Primero, las desapariciones en el pueblo llevadas a cabo por grupos armados que no se identifican con claridad. Los habitantes del pueblo los llamaban "Ios ejércitos", ya que no sabían con certeza si eran militares, paramilitares o guerrilla. En medio de la incertidumbre (las acciones violentas, los ataques a la población y tener que esconderse en un total estado de indefensión), Otilia desaparece e Ismael emprende su búsqueda para finalmente darse cuenta de que su pueblo, San José, había quedado despojado de todo cuanto conocía y que probablemente ella nunca regresaría (Rosero 2015). El pueblo solo guardaba los ecos de los habitantes que se habían marchado dejando su hogar para emprender un camino sin retorno.

A la altura de la escuela encuentro un grupo de gente caminando en fila, en dirección a la carretera. Se van de San José: debieron pensar lo mismo que yo; son un gran pedazo de pueblo que se va. Lentos y maltrechos — hombres, mujeres, viejos y niños- ya no corren. Son una sombra de caras en suspenso, ante mí, las comadres rezan a balbuceos, uno que otro hombre se empecina en acarrear las pertenencias de más valor, ropa, víveres, hasta un televisor, ¿y usted no se va, profesor? No, yo me quedo —-me escucho a mí mismo resolver. Y aquí me quedo entre la sombra caliente de las casas abandonadas, los árboles mudos, me despido de todos agitando esta mano, yo me quedo, Dios, yo me quedo, me quedo porque solo aquí podría encontrarte, Otilia, solo aquí podría esperarte, y si no vienes, no vengas, pero yo me quedo aquí. (Rosero 2015, 169) 
En la descripción de Ismael de cómo sus vecinos (a quienes se les negó la posibilidad de identificarse y reflejarse en su territorio a causa de las acciones violentas que conllevaron el desplazamiento de la población), se van alejando del pueblo, se construye la imagen de desarraigo: un grupo de personas que se desplaza como sombras en estado de perplejidad con un semblante de desilusión. El sentimiento de tristeza se hace patente en varias partes del libro, donde los habitantes del pueblo manifiestan dolor por tener que dejar lo que han construido con esfuerzo y entender que no regresarán al lugar que imaginaron para vivir toda la vida (Rosero 2015).

Mi familia pasó por esos cuestionamientos. Al dejar Santa Helena, mis abuelos y sus hijos se transformaron también en sombras que marchaban rumbo a un paisaje desconocido, llevando consigo los pocos enseres que podían cargar. La casa quedó abandonada, silenciosa, a la espera de ser habitada de nuevo pero eso nunca ocurrió. El sonido del cacho, alarma de resguardo y protección, dejó de trazar los límites del territorio porque la familia, cansada de esconderse, ya no quiso escuchar su llamado. En la vereda, quedaron los animales, las plantaciones de café, la escuela, las relaciones establecidas con los vecinos y la mesa grande del comedor en la que convergía la unión familiar. Eso fue lo que les arrancaron, el vínculo y el amor al terruño, y mis tías debieron vivir con la sensación de esa pérdida, ese desprendimiento, esa dificultad para echar raíces. Una dificultad que podía ser superada, en parte, encontrando un espacio en el cual resguardar el hogar, ya que la unión familiar y el afecto seguían presentes. Por el camino de herradura la familia emprendió un largo viaje, de un día completo, sintiendo incertidumbre pero anhelando hallar lo que había perdido, así, alrededor de 1960, llega en medio de la niebla a Anzoátegui.

\section{MEMORIAS DEL DESARRAIGO DE UNA CASA ONÍRICA}

Esta investigación tuvo como punto de partida mi llegada a Anzoátegui cincuenta y seis años después de que se diera la migración forzosa de mi familia. El municipio, desdibujado por la niebla, conservaba en sus estructuras parte de la apariencia que mis tías recordaban. Aún se podían encontrar el cementerio, la plaza de mercado, el colegio, la plaza central y la iglesia. La casa de mi familia era pequeña, pero acogedora. Su fachada era en cemento y su interior en madera. La mayoría de los cuartos estaban pintados de amarillo y aunque su color era distinto del original, pese al tiempo, conservaba el estilo de sus ventanas en madera (figura 3a). La casa tenía un sótano que estaba clausurado (figura $3 b$ ) y del que solo se alcazaba a entrever una parte por medio de una abertura que tenía el piso. Ese lugar tenía una carga fuerte para la familia por ser el espacio donde se escondían sus miembros cuando ocurrían las tomas del pueblo o los ataques en cercanías a este.

La ruta marcada para mi viaje comprendió Anzoátegui, Lisboa, Santa Helena y, finalmente, Ibagué. En este recorrido, los relatos de mis tías fueron el eje central para identificar los espacios en los que habían vivido. En cada lugar, existían elementos similares que se mantenían pese al paso de los años, como es el caso de los balcones decorados con flores de distintas especies. Solo un espacio fundamental de los relatos había desaparecido, la casa de Santa Helena, que se había quemado tiempo después de que mi familia se marchara. Lo único que encontramos referente a la época de 1950 eran los cimientos de cemento de la casa y la pileta donde se recogía el agua. La única forma de aproximarnos a la idea de cómo era ese espacio 


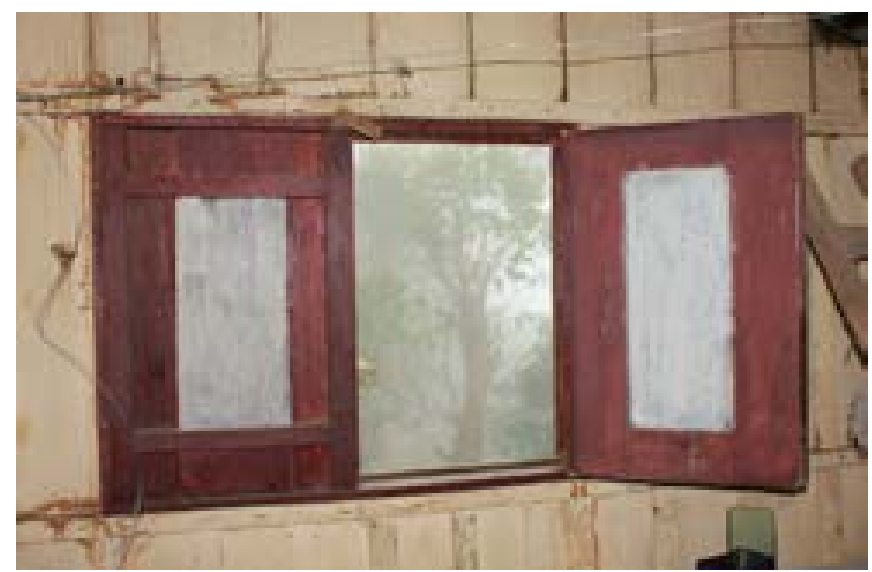

Imagen 3a. Ventana en madera de casa en Anzoátegui. Foto: Estefany Alfaro Buitrago.

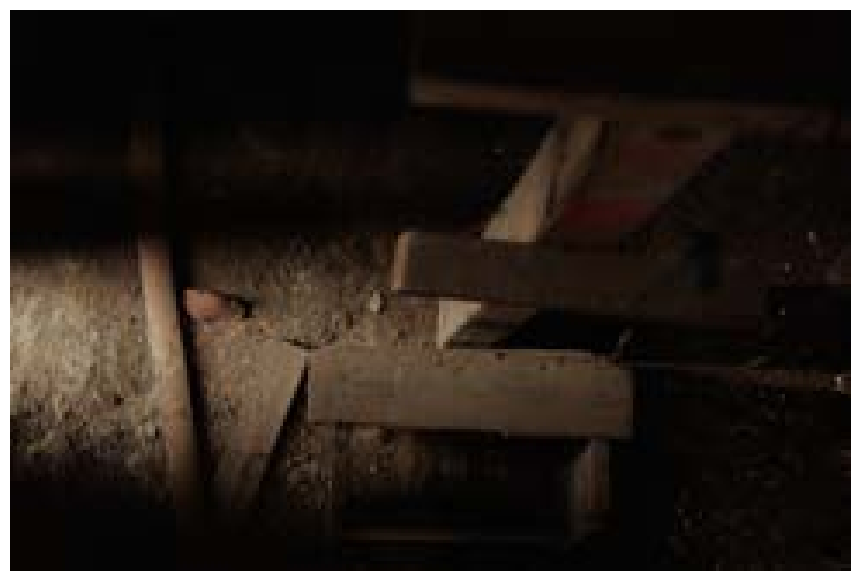

Entrada al sótano de la casa, Octubre 2016, Anzoátegui Tolima. Foto: Estefany Alfaro Buitrago.

fue por medio de las palabras de Amanda, de sus recuerdos, que proporcionaron pistas de la ubicación del comedor, del cuarto de los aparejos, de la cocina, las habitaciones y la sala. Fue necesario apelar a la imaginación para transportarme a ese tiempo y hacer un ejercicio de observación detallada de los vestigios que quedaban para mirar de la misma forma en que lo haría el hombre de la lupa.

Según Bachelard (1997, 191-192), el ejercicio de observación minuciosa nos convierte en el hombre de la lupa, aquel que descubre el mundo a partir de la experiencia de mirar por primera vez. Este ejercicio parte de la noción de miniatura que se refiere a hallar la grandeza en lo pequeño. Es decir, no tener la mirada objetiva del científico, por el contrario, recurrir a la imaginación onírica para descubrir imágenes (de la fantasía, del recuerdo), capturar los detalles que pasan desapercibidos, poner atención y amplificar lo inadvertido. Por medio de ese tipo de observación, por instantes, sentí destellos del hogar que añoraban mis tías, y percibí paredes que habían desaparecido. Aunque Amanda pensaba que no quedaba nada con que identificarse, al ver los cimientos de la casa transformó su expresión, porque esos simples objetos eran los vínculos que la remitían a su niñez, eran las huellas de la casa que había desaparecido.

Percibir la realidad, tal como lo hace el hombre de la lupa, me acercó a la casa onírica evocada por mis tías. Al centrarme en la experiencia del viaje, y en las descripciones de ellas sobre la casa, que comprendían impresiones como el color de las cosas, los tamaños de los espacios y objetos, o relaciones como las distancias, el frío, la luz y la oscuridad, me aproximé a las afecciones que sentía mi familia. Allí estaba el alma de la casa, lo esencial que proporcionaba bienestar y calidez para quienes la habitaban. Era una casa fantasma porque su existencia estaba supeditada a los recuerdos de mis tías y a la forma como la habían imaginado en la infancia.

De la inquietud abierta a partir de ese momento surgieron los cuestionamientos por cómo las fuerzas expresivas contenidas en los relatos podrían ser traídas a la presencia. Esto sugirió que tal vez a través del poder expresivo y evocador del arte podría encontrar maneras de volver tangible la casa fantasma. Partiendo de entender el arte como un problema de pensamiento que permite, a través de la experimentación de los materiales y del proceso creativo, una reflexión sobre el hogar, me hago la pregunta ¿cómo evocar a través del arte la casa de Santa Helena? ¿Cómo volverla tangible? 
Los testimonios eran fundamentales, con la precisión de sus detalles y también con los vacíos y las ausencias. El dibujo hecho por Gloria (figura 4), evocación de su recuerdo de la casa, fue el primer indicio por seguir para expresar las fuerzas constitutivas del arraigo hacia el terruño. El llamado al poder evocador del arte, más allá de dar preponderancia al resultado final, hizo evidente que lo fundamental en el esfuerzo de traer a la presencia la evocación de los recuerdos del desarraigo es el proceso de búsqueda. En este sentido, fue esencial pensar en la técnica como medio expresivo del concepto de hogar.

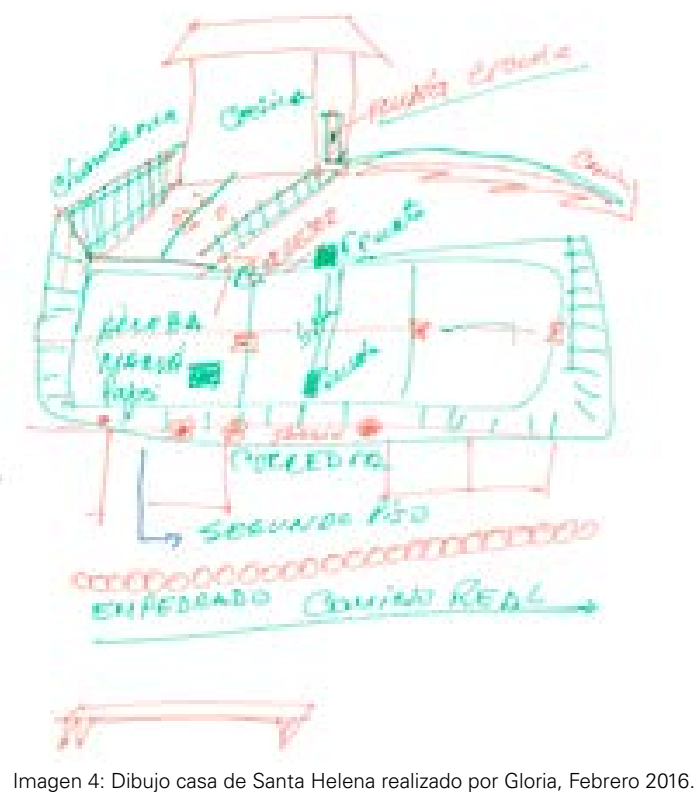

Gloria manifestaba que en la construcción del hogar estaba implícito el esfuerzo del cuerpo, partiendo de modelar con las propias manos la casa como una masa de barro. Desde mi interés en probar las potencialidades del arte para desentrañar las fuerzas presentes, realicé un ejercicio similar: reconstruí con mis manos los espacios que mis tías creían importantes de la casa en Santa Helena, por medio de maquetas. Las palabras de mi tía, sobre todo su carga de alusiones atmosféricas, las referencias al sentido afectivo del ambiente producido por objetos, espacios y seres, sugirió que las maquetas formaran parte de dioramas.

Debido a la connotación afectiva de los espacios, en la creación plástica, estaban presentes las nociones de expansión y contracción. Es decir, las pautas de elaboración de los dioramas provenían de cómo mi familia había percibido los lugares, cómo los habían sentido, a veces seguros, otras veces frágiles. Rehíce otros lugares en los que vivió mi familia como Anzoátegui, Lisboa e lbagué, porque en estos se hacían patentes las dinámicas de vivir en medio de la guerra. Algo que da cuenta de este hecho es el diorama de la casa de Lisboa.

En esa escena (figura 5), se recreó el momento en que mis tías Gloria y Marisol estaban escondidas, porque la chusma se iba a entrar en el corregimiento para atacarlo en 1955. Como único medio de protección, usaron como trincheras los colchones de la casa y mis tías se escondieron debajo de la cama. Esto se hacía para evitar que las balas entraran directamente a la casa, ya que las paredes eran de madera. Cuando escuché esta historia, percibí cómo Gloria y Marisol equiparaban los colchones a murallas, pese a ser frágiles y los convertían en una suerte de refugio para suspender por un instante el miedo. 


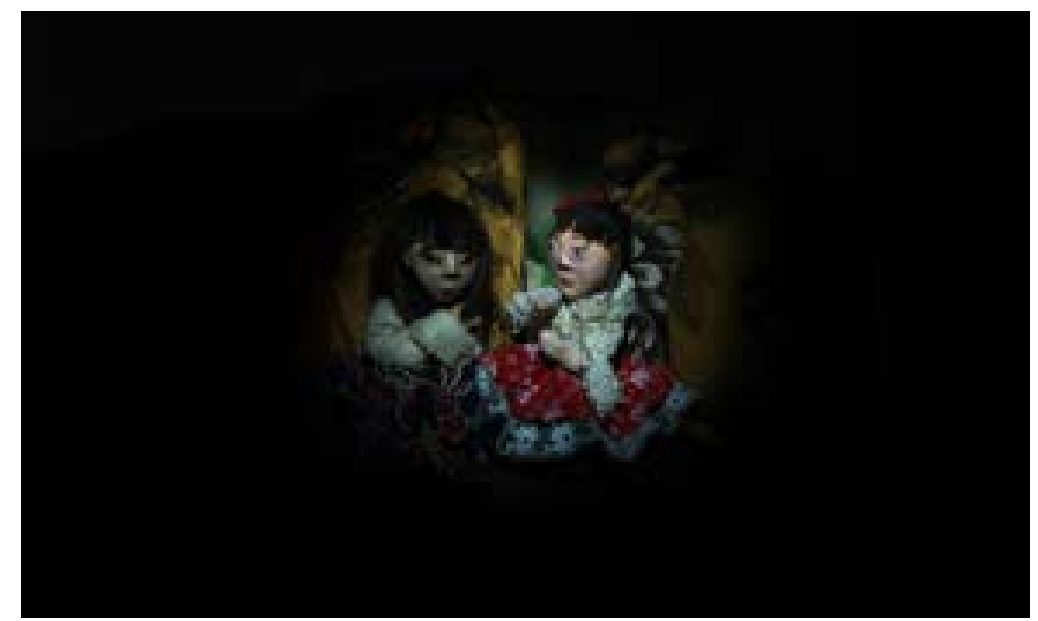

Imagen 5. Cartografías de migración y desarraigo, detalle diorama casa de Lisboa, Junio 2016. Foto: Estefany Alfaro Buitrago

En la creación del diorama (figura 6), eliminé las paredes para resaltar el resguardo que les proveían los colchones a mis tías y modelé sus cuerpos a una escala menor. En ese punto, fue esencial hacer ensayos de composición (figura 7) y así determinar la ubicación de los colchones en el espacio con el propósito de conformar las trincheras, decidir los vacíos y hacer pruebas de iluminación que aportarían en la construcción de esa atmósfera.

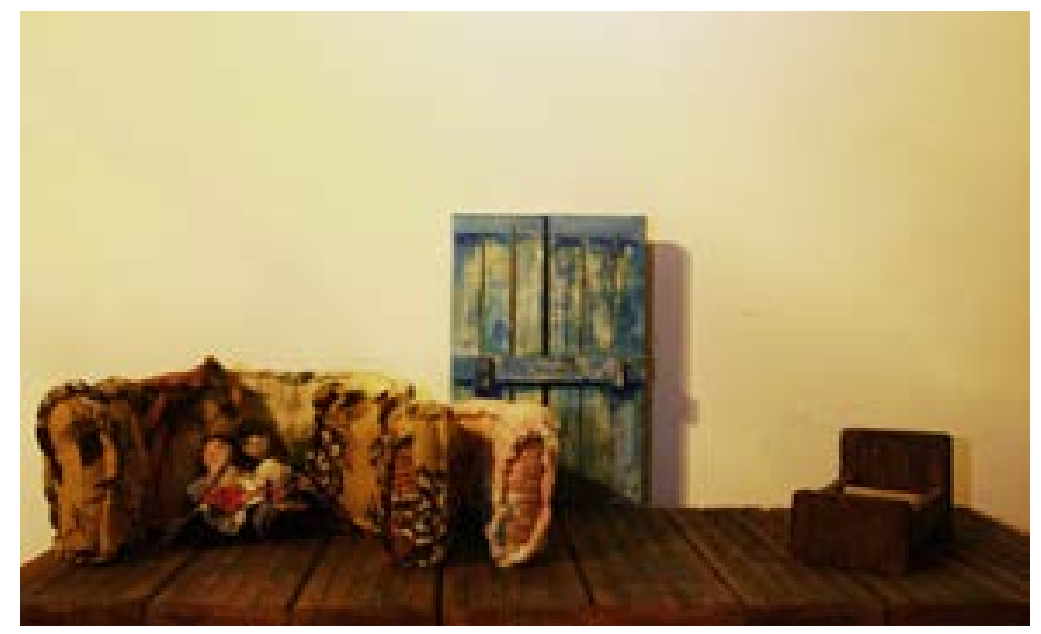

Imagen 6. Cartografías de migración y desarraigo, vista general diorama de Lisboa, énfasis en ausencia de paredes, Junio 2016. Foto: Estefany Alfaro Buitrago.

Una imagen que se contraponía al acontecimiento violento de Lisboa era la casa de Santa Helena, que se reconstruyó por medio de tres espacios: la cocina, el comedor y el cuarto de los aparejos. Cada uno se elaboró como un diorama independiente, que simbolizaba el alma de la casa, su vitalidad y lo esencial, que proporcionaba calor de hogar. El cuarto de los aparejos, ubicado en la planta inferior de la casa debajo del comedor, era el lugar vedado para los niños porque podía resultar peligroso, ya que ahí se guardaban las herramientas de trabajo. Para hacer la composición del espacio con los objetos que hacían parte de él, se realizó un boceto (figura 8) a partir de los relatos de Amanda que describían cómo eran los aperos, las enjalmas, las horquetas en las que se colgaban las herramientas, el carriel y los estribos en bronce. 

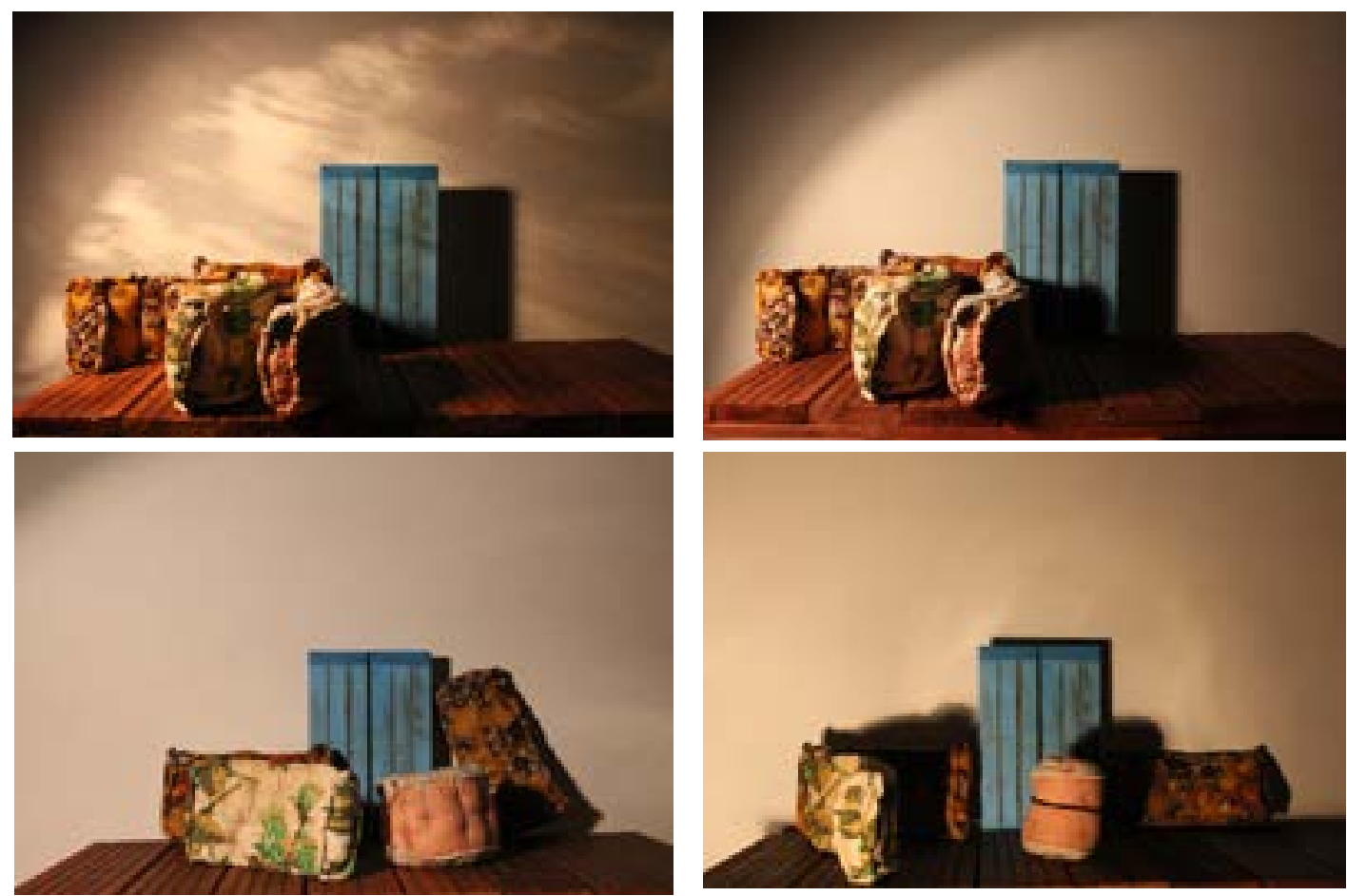

Imágenes 7 a, b, c y d. Cartografías de migración y desarraigo, ejercicios de composición, determinación de posición de colchones dentro del diorama de Lisboa, Junio 2016. Fotos: Estefany Alfaro Buitrago.

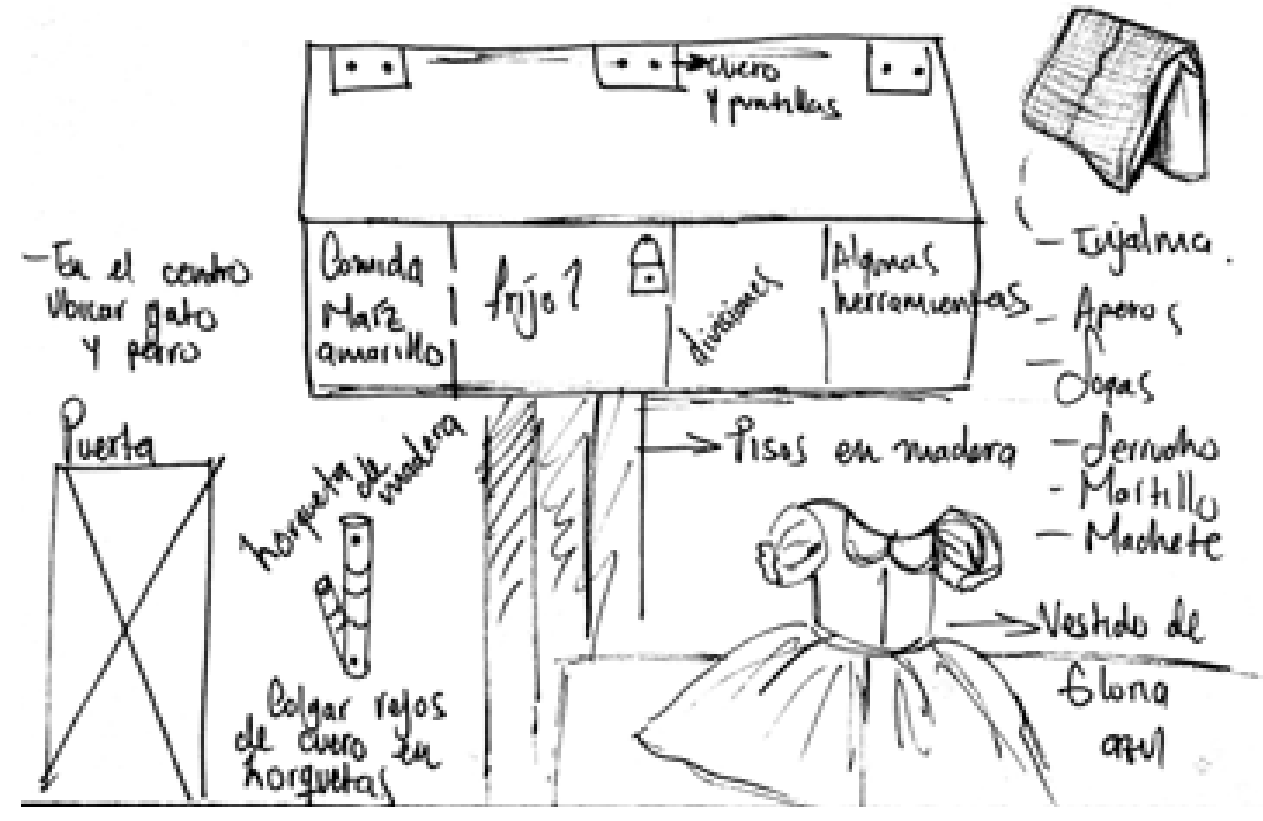

Imagen 8. Cartografías de migración y desarraigo, boceto de objetos que hacían parte del cuarto de los aparejos a partir de relato de Amanda, Septiembre 2016. Foto: Estefany Alfaro Buitrago. 
Otra fuente importante fue el registro fotográfico tomado durante el viaje como punto de referencia para construir los baúles (figura 9a) con los detalles que les eran característicos. El candado del cuarto de los aparejos incitaba la curiosidad de mis tías y era la invitación para imaginarse las cosas que se podrían encontrar dentro de los grandes baúles de madera (figura 9b) que estaban ubicados hacia los costados de las paredes.

La escena que se albergaba en el interior era el momento de juego de mi tía Gloria con sus mascotas: un perro y un gato (figura 10). Ese instante de esparcimiento estaba delimitado por la colcha de retazos en tela de distintos colores, que era un elemento significativo para mis tías, ya que cuando eran niñas mi abuela Amalia solía tejer distintos tipos de colchas para ellas. En este espacio, se creaba la posibilidad de habitar lo prohibido, ya que cuando Gloria era niña solo la dejaban jugar en los alrededores del cuarto.

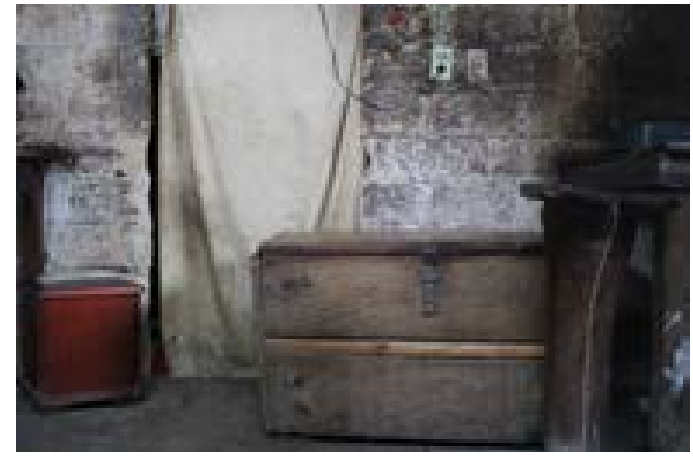

Imagen 9a. Cartografías de migración y desarraigo, fotografía baúl en madera, Santa Helena, Tolima, Octubre 2016.

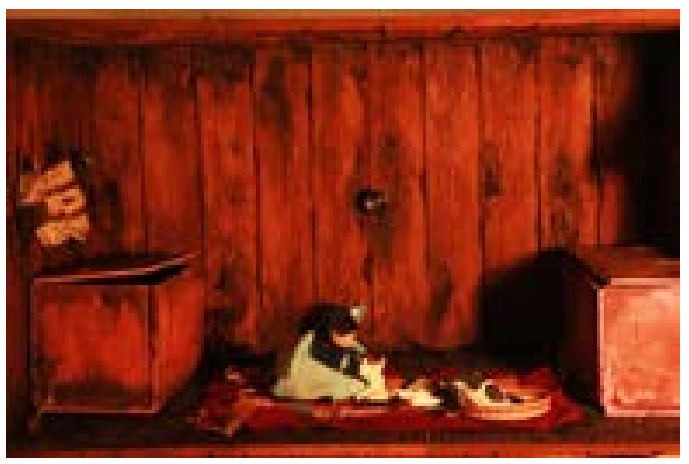

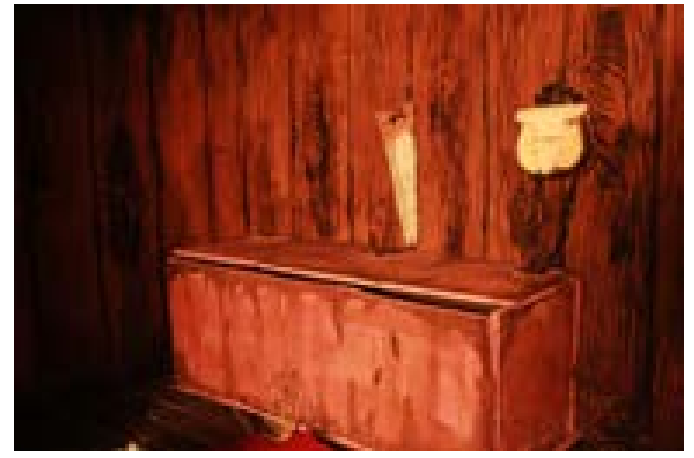

Imagen 9b. Fotografía detalle diorama cuarto de los aparejos, énfasis en baúl. Fotos: Estefany Alfaro Buitrago.

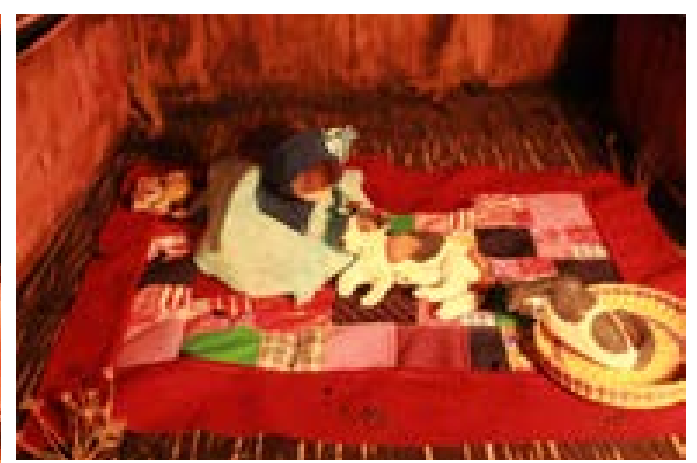

Imágenes 10 a y b. Cartografías de migración y desarraigo, detalles diorama cuarto de los aparejos, espacio de juego de Gloria, Octubre 2016. Fotos: Estefany Alfaro Buitrago.

El proceso creativo de este diorama sugirió la importancia de la presencia de la oscuridad como personaje (figura 11). Con ese propósito, se emprendió la exploración, por medio del registro fotográfico, de la creación de distintas atmósferas de la misma escena a partir de la ubicación de diferentes puntos focales de luz para observar las variaciones que se iban generando sobre los objetos. A través de la sombra, se evocaba el misterio del espacio, que tenía solo un orificio en su exterior para permitir que entrara la mirada curiosa del espectador.

Las pautas de creación de la cocina y el comedor se basaron en las primeras entrevistas a mis tías Gloria, Marisol y Amanda. El primer momento del proceso consistió en extraer los fragmentos alusivos a estos espacios. El segundo, en hacer otras entrevistas con el propósito de ahondar en la información. La creación de la cocina se centró en tres objetos: 
la estufa de leña, dos maderas pegadas a la pared que funcionaban como sillas y la alacena. La estufa con las sillas evocaba la casa onírica (figura 12); era fuente de calidez, como lo manifestaba Amanda: "el lugar para soñar." Alrededor de la estufa mis tíos se reunían a escuchar las historias de Timbillas y dejaban que la imaginación guiara ese encuentro. Por otra parte, la alacena evocaba la finca de Santa Helena porque en su interior estaban los pocillos y platos de loza esmaltada que solía usar mi abuela para atender a las visitas; era un recuerdo que tenía muy presente mi tía Marisol.
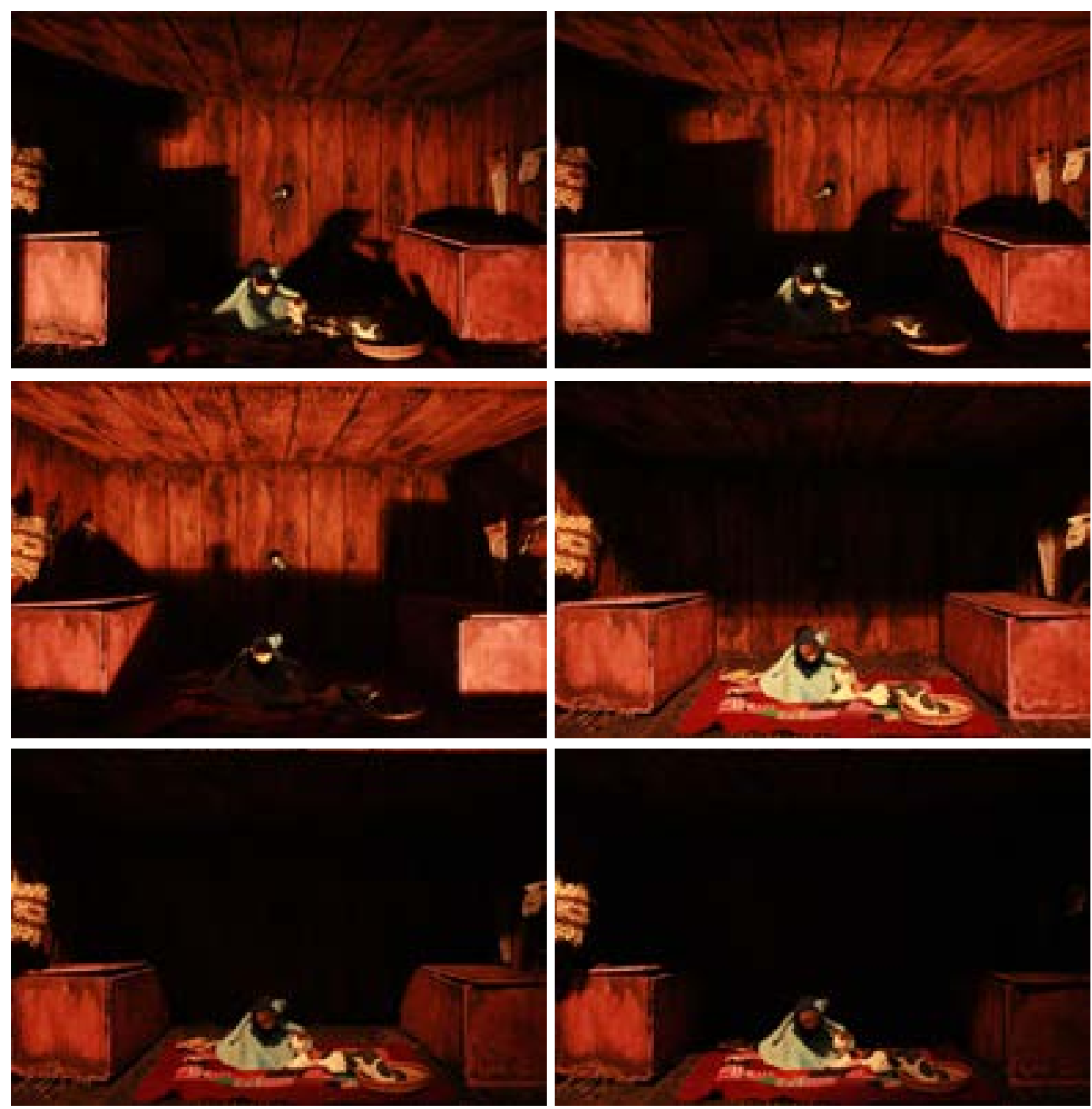

Imágenes 11 a, b, c, d, e y f. Cartografías de migración y desarraigo, variaciones de luz en diorama cuarto de los aparejos, Octubre 2016. Fotos: Estefany Alfaro Buitrago.

El comedor tenía una particularidad. En lugar de tener paredes en dos de sus costados, tenía cercas de madera decoradas con plantas, que funcionaban como balcones que proporcionaban una vista panorámica del paisaje. Para la creación de los balcones, tomé como referencia una fotografía del álbum familiar (figura 13) en el que aparecía la fachada de la casa. En el diorama, se realizaron las maquetas de la mesa del comedor, los taburetes de madera 
y las bancas. Como punto de partida para la creación de los muebles, usé una fotografía tomada durante el viaje de la casa (figura 14) que perteneció a mis bisabuelos en Santa Helena. La decisión de recrear ese espacio partió del hecho de que Gloria y Marisol lo consideraban importante, porque la mesa del comedor simbolizaba para ellas la unión familiar. La acción de compartir los alimentos propiciaba el diálogo entre los integrantes de la familia.
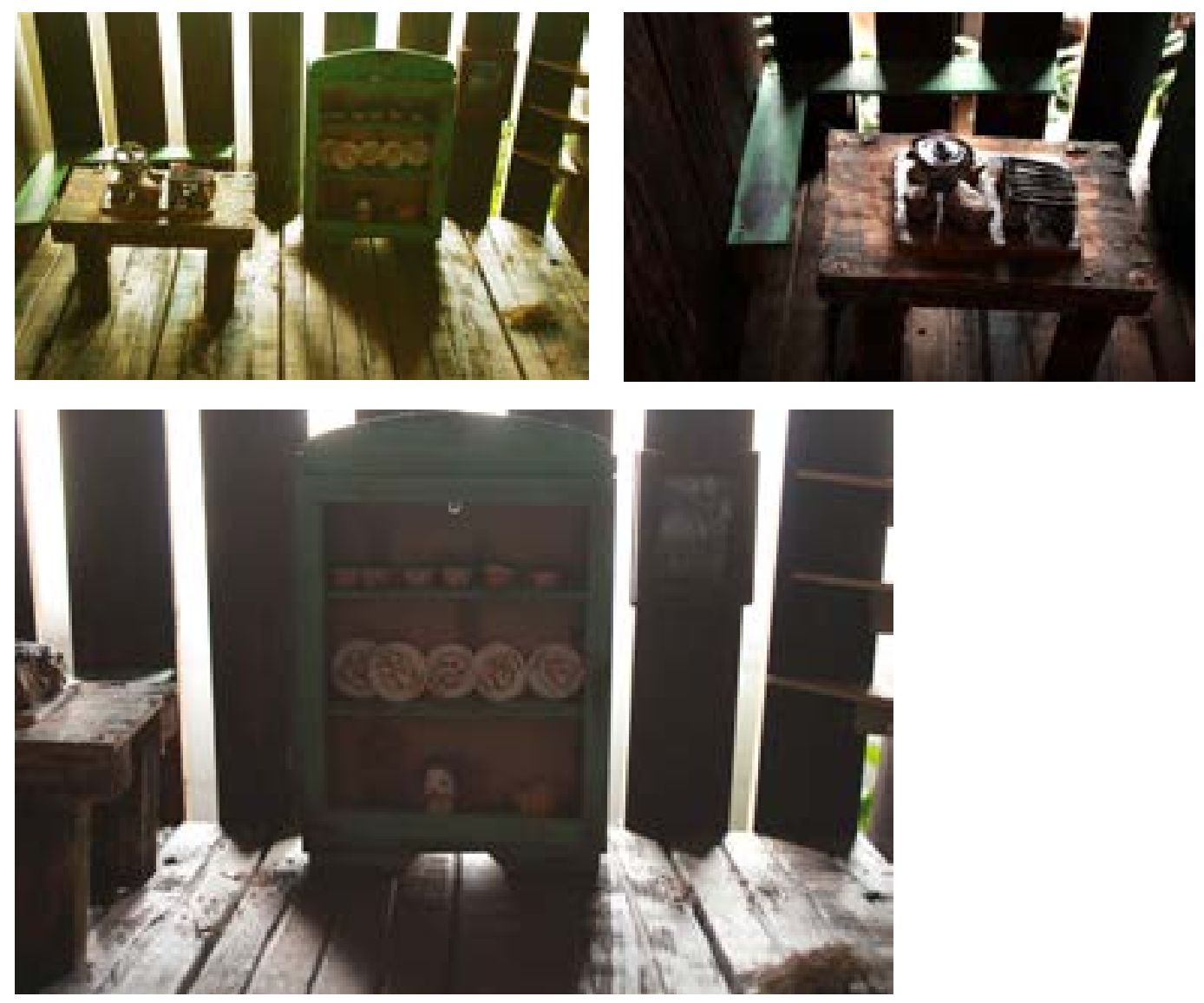

Imágenes 12 a, b y c. Cartografías de migración y desarraigo, vista general y detalles del diorama de la cocina de casa en Santa Helena, Julio 2016. Fotos: Estefany Alfaro Buitrago.

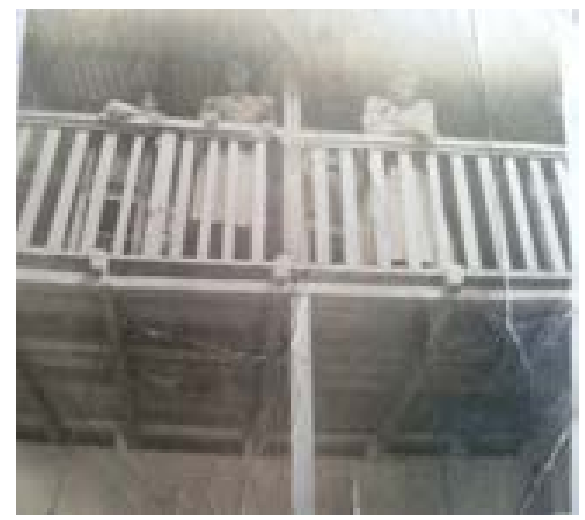

Imagen 13 a. Fachada de casa en Santa Helena. Álbum familiar.

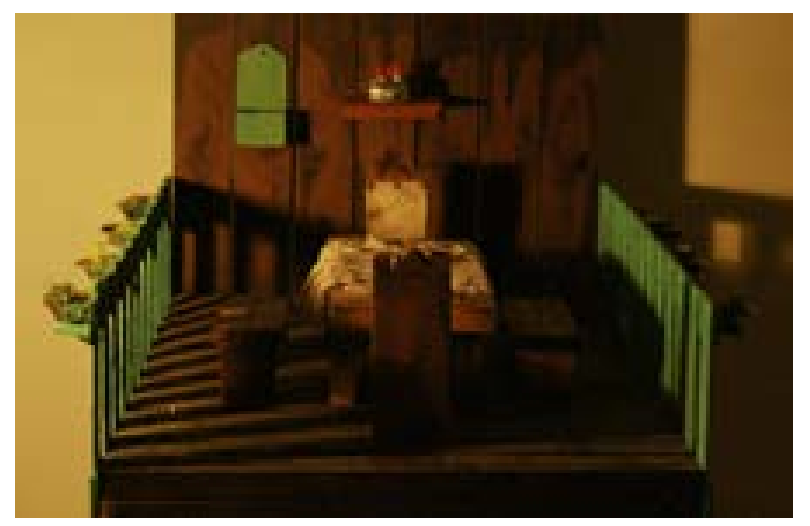

Imagen 13 b. Cartografías de migración y desarraigo, detalle de diorama comedor en Santa Helena, Octubre 2016. Foto: Estefany Alfaro Buitrago. 


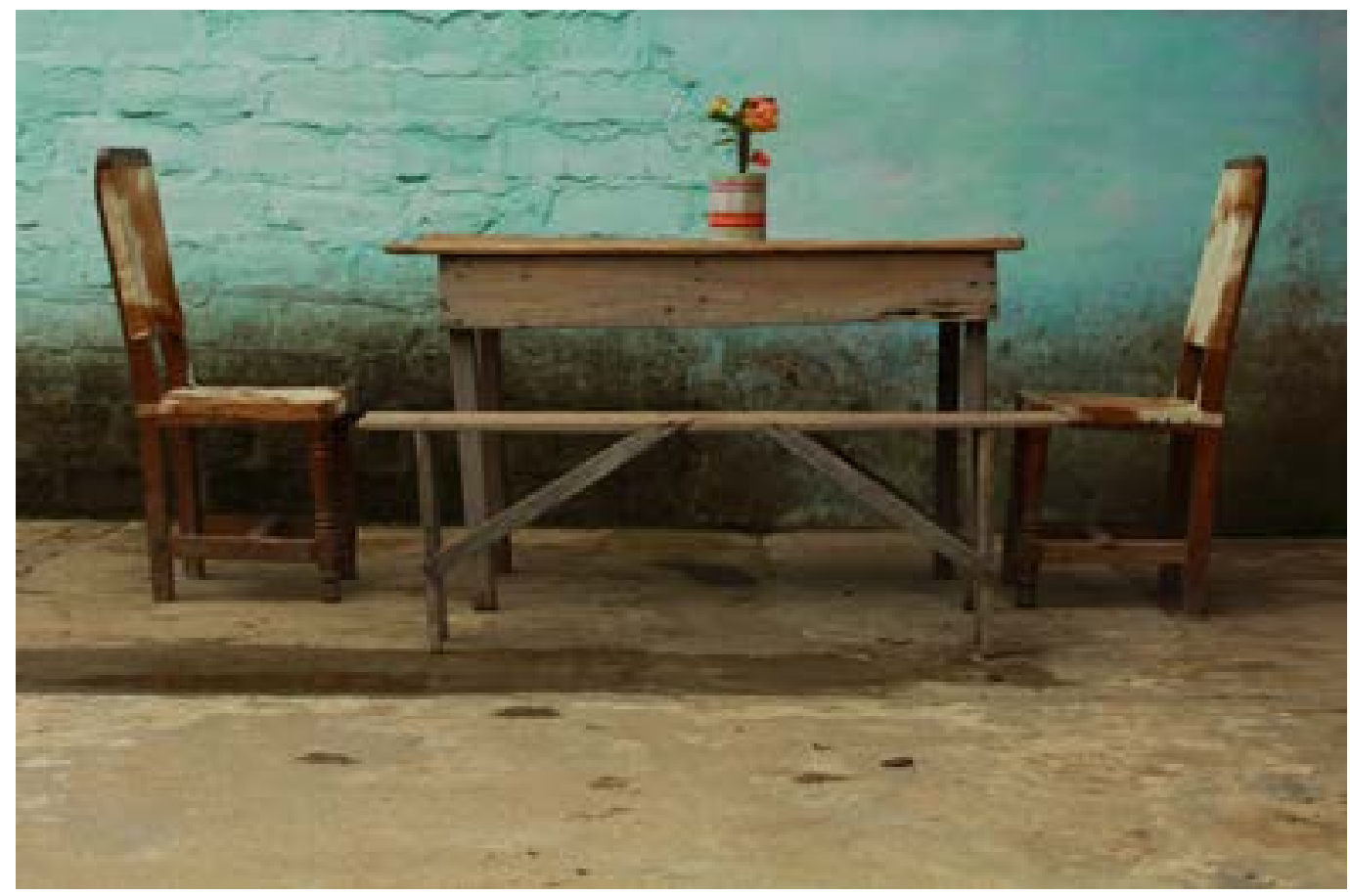

Imagen 14. Comedor casa que perteneció a mis bisabuelos en Santa Helena, Tolima, Octubre 2016. Foto: Estefany Alfaro Buitrago.

Evocar la construcción del hogar desde el cuerpo era la intención del diorama de la casa de Ibagué. La tía Ema con su amor y cuidado hacia Gloria, Marisol, Stella y Amanda, había trazado un territorio a su alrededor que les proveía seguridad, estabilidad y arraigo. El diorama surgió de la reconstrucción de una fotografía en la que Ema cargaba a mi mamá, donde estaban presentes esos cuidados (figura 15). Lo fundamental de esta imagen era la figura de Ema que encarnaba el territorio y el arraigo, por esta razón solo aparece un fragmento de la fachada de la casa como una especie de contracción del espacio. Entre los detalles de la escena, estaba el piso de baldosa con motivos florales que resultaba importante en la medida en que rememora la época. Cada uno de los detalles, como el color del piso, las paredes, el vestido de la niña, daban pequeñas pistas de cómo era la casa y de lo que representaba para ellas.

Persistir en el ejercicio de rememorar una y otra vez la misma imagen no se presenta como una acción desgastante sino vital, porque es la forma de mantener latentes los lazos de unión con el territorio. Las líneas imaginarias de las moradas que, en coexistencia con las fuerzas de la guerra constituían el terruño, surgían de la repetición, por parte de mis tías, de algunos acontecimientos de la historia familiar. Los testimonios cuidadosamente entretejidos daban forma a las imágenes, construidas a partir de los detalles que reflejaban la carga emocional que tenía para ellas lo narrado. Era un territorio abstracto, que tomaba cuerpo a través de los dioramas y reflejaban en simultáneo relaciones concretas entre distintos espacios y temporalidades.

El diorama sobre el espacio de Lisboa, alusivo al periodo de 1955, se centró en la creación de una atmósfera de protección y resguardo donde Gloria y Marisol usaban los colchones como trincheras ante la amenaza del arribo de la chusma al corregimiento. El interior de la casa se reorganizaba para hacer frente a las fuerzas de la guerra para preservar la vida. El miedo, experimentado por mis tías, obedecía en parte a que se encontraban lejos de la protección de sus padres y del apoyo de sus hermanos. 


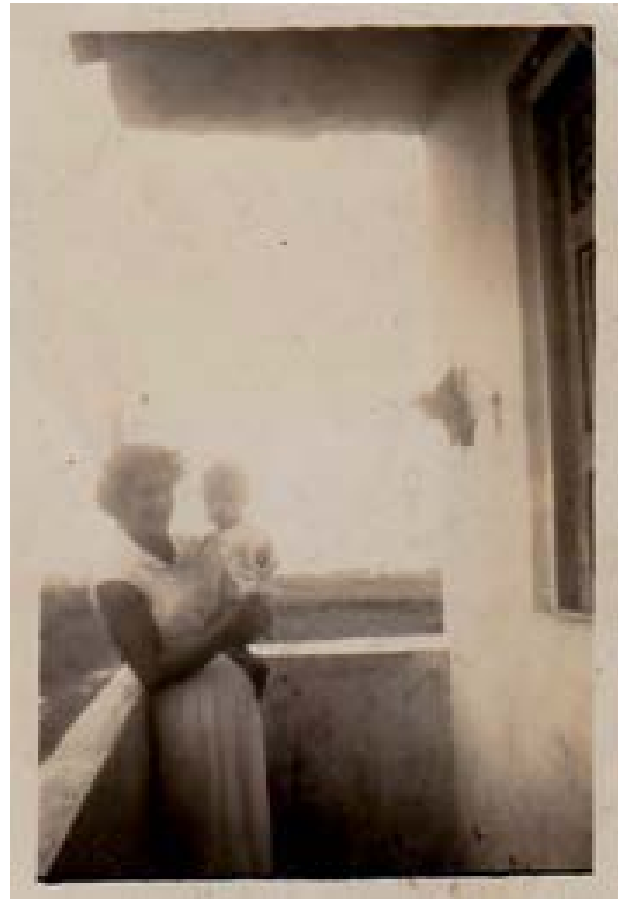

Imagen 15a. Balcón casa de Ibagué, Ema cargando a Stella. Foto álbum familiar.

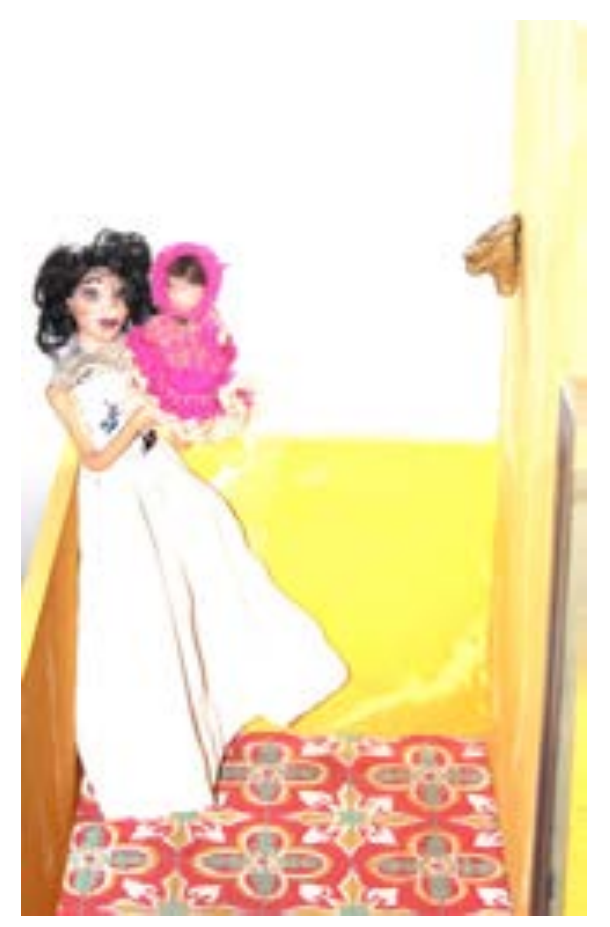

Imagen 15b. Cartografías de migración y desarraigo, detalle diorama casa Ibagué, Agosto 2016. Foto: Estefany Alfaro Buitrago.

Al hacer el ejercicio de ubicar en paralelo la escena del cuarto de los aparejos con la de Lisboa (figura 16), se contrapone la imagen de Gloria unos años atrás, alrededor de 1952, jugando con sus animales en Santa Helena. Ambos lugares funcionaban como centros de protección, pero de maneras distintas: el primero se oponía a la entrada de las fuerzas destructivas de la guerra y el segundo anidaba el espacio de juego que partía del cuidado de los animales. Estas escenas daban cuenta de las tensiones de vivir en medio de la violencia, contrastando momentos de calma con instantes de angustia.

Los dioramas de la cocina y el comedor (figura 17), alusivos a comienzos de la época de 1950, en relación con el espacio de Ibagué (figura 18), periodo de 1957, evocan la construcción del hogar. La cocina y el comedor hacen parte de la casa de la infancia que les proporcionaba a mis tías tranquilidad y bienestar. En lbagué, la sensación de calidez provenía de la presencia de la tía Ema (que les daba estabilidad a mis tías y a mi mamá), quien sopesaba lo que habían perdido. Aunque fue el periodo en el que estuvieron lejos de la casa en la que nacieron,
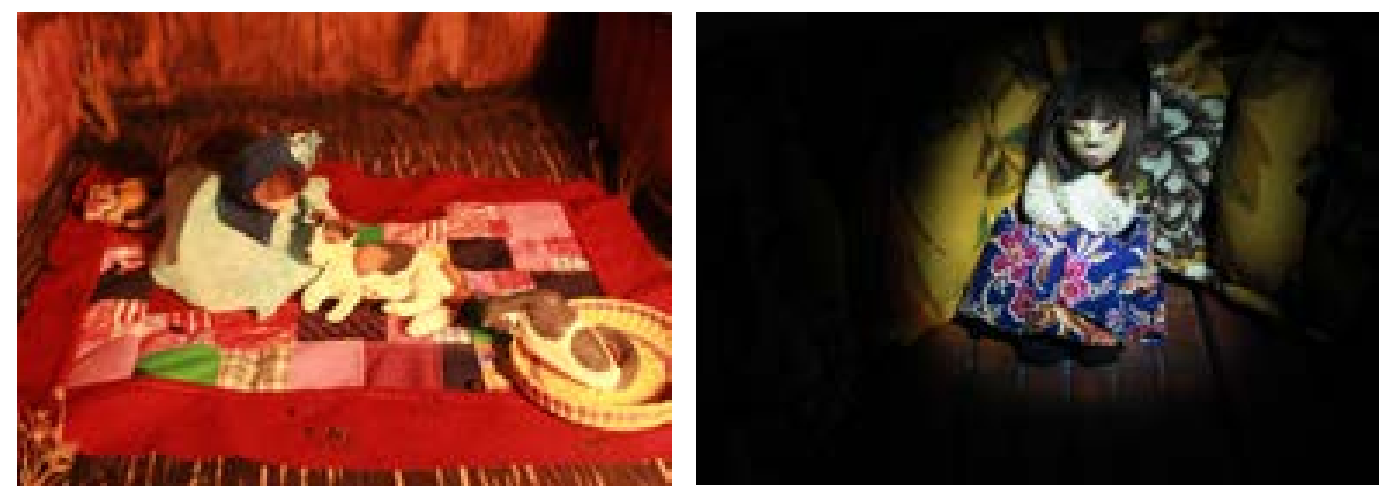

Imágenes 16a y b. Cartografías de migración y desarraigo, detalles de diorama de cuarto de los aparejos y de Lisboa, énfasis en el resguardo provisto por ambos espacios. Fotos: Estefany Alfaro Buitrago. 

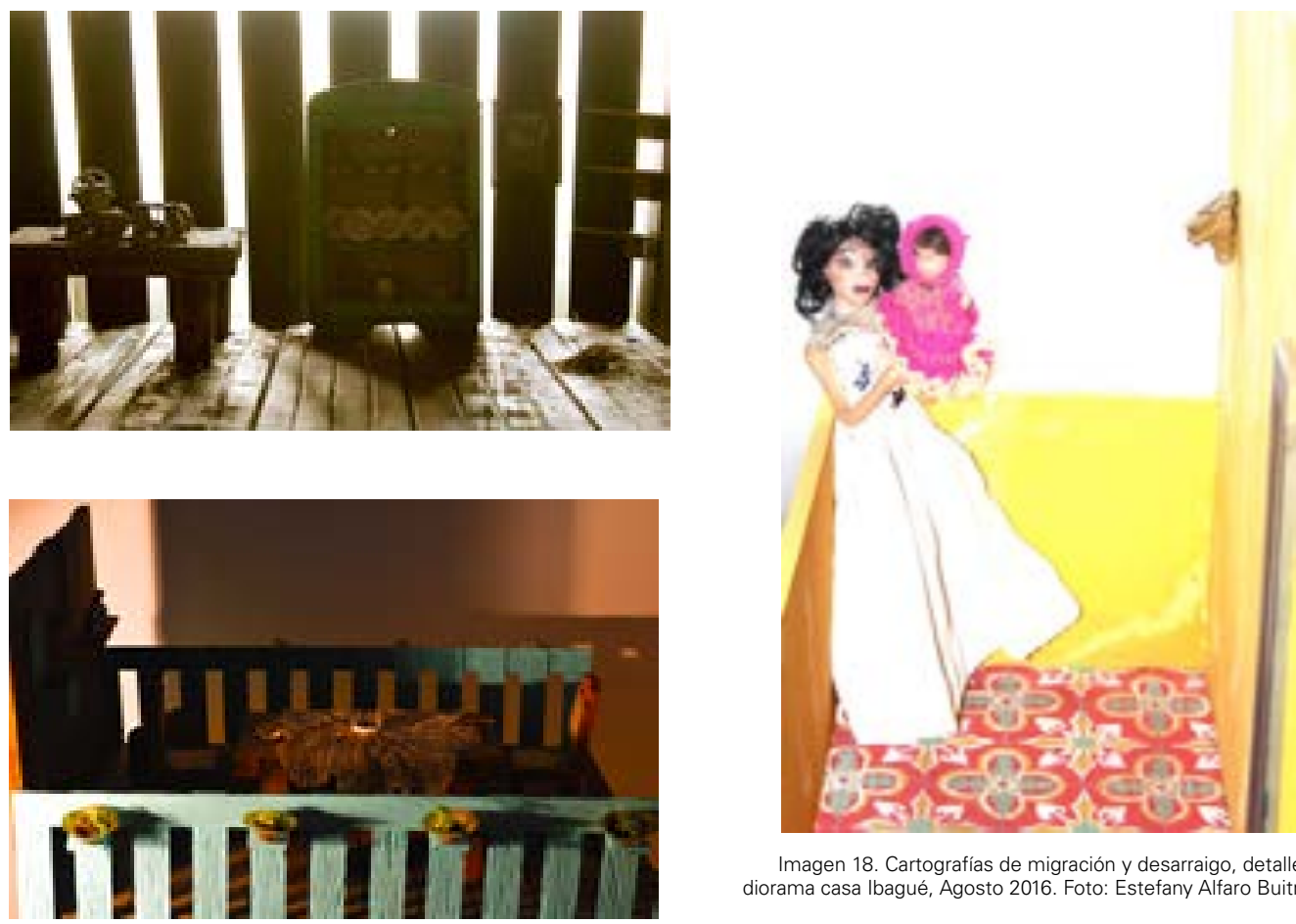

Imagen 18. Cartografías de migración y desarraigo, detalle diorama casa Ibagué, Agosto 2016. Foto: Estefany Alfaro Buitrago.

Imágenes 17 a y b. Cartografías de migración y desarraigo, dioramas cocina y comedor. Foto: Estefany Alfaro Buitrago.

sintieron por primera vez, desde que se marcharon de Santa Helena, que era posible recuperar la tranquilidad. Ambos espacios apelan a la vida y a los afectos; uno desde los objetos que simbolizan la morada y el otro desde el cuerpo como hogar.

Pensar los dioramas en conjunto abre la posibilidad de entenderlos como una cartografía que visibiliza las tensiones experimentadas por mi familia a partir de las migraciones de Santa Helena a Ibagué y Santa Helena a Anzoátegui. De este modo, los dioramas constituyen puntos de referencia dentro de un territorio que continúa en proceso de creación en busca de evocar el hogar, los espacios de esparcimiento y las dinámicas de la guerra. Búsqueda que tiene como eje la experimentación de luz y sombra, donde por medio de la penumbra se alude a los vacíos y las imprecisiones de los recuerdos de mis tías. La continuidad de este proceso resulta vital porque amplía el panorama de las implicaciones que tuvo para la familia vivir en la década de 1950 en el departamento del Tolima. 


\section{CONSIDERACIONES FINALES}

Se puede evidenciar a partir de las definiciones de Marisol, Gloria y Amanda, expuestas párrafos atrás, que el hogar se constituye a partir de los vínculos afectivos, de cuidar el espacio por medio del mantenimiento y la organización de los objetos. Cuidado que no se limita a la casa como estructura, sino también a las personas que viven en ella. Es el lugar donde la familia se establece y se desarrolla. Llegan los nuevos hijos y hay un futuro sostenible para ellos. Además, se edifica como centro de descanso de las actividades laborales. Estas nociones del hogar parten de la casa de Santa Helena, el lugar en el que vivieron su infancia. Este ciclo se interrumpe por la presencia de la guerra, que se manifestó en las amenazas continuas de posibles ataques a la vereda. Estas circunstancias llevaron a implantar la dinámica de huir en las noches hacia el monte para evitar ser encontrados y asesinados en las casas. En este punto, la casa pierde su carácter protector y los agresores pueden franquear sus fronteras y hacerla vulnerable.

Las fuerzas desterritorializantes presentes al huir y las fuerzas territorializantes al retornar al hogar se convirtieron en prácticas desgastantes ante la permanencia del conflicto, lo cual ocasionó el abandono definitivo de Santa Helena por parte de la familia. De esa ruptura surgió el desarraigo como manifestación dolorosa frente al distanciamiento inevitable con el territorio. Mis tías asumieron estos acontecimientos como la pérdida del lugar en el que asirse, adoptando una posición de desprendimiento frente a la vida. No obstante, hubo una fuerza vital que impulsó a la familia a seguir adelante y a buscar un lugar diferente para forjar un territorio que se convertiría en su morada, transponiendo las características fundamentales que constituían un hogar.

Las migraciones de mi familia tuvieron un impacto distinto en cada una de mis tías. Para Amanda, sentir que no pertenecía a ningún sitio y la indiferencia frente a los lugares que había habitado después de Santa Helena eran parte de las marcas dejadas por el desarraigo. Para Marisol, lo que persistía del abandono de su hogar de infancia era el desapego de las cosas y la imposibilidad de crear lazos consistentes con el terruño. Gloria presentaba una visión más esperanzadora frente a la posibilidad de recuperar el arraigo, manifestando que era posible restablecer esos vínculos con el lugar que uno habitaba a partir de la persistencia, que partía de querer lo que se tenía, aunque fuera poco, y de cuidar su crecimiento. Es como tener una planta y regarla día tras día, así por medio de los cuidados se va forjando un porvenir próspero. Sin embargo, esta percepción no es del todo positiva, ya que subsiste la desconfianza hacia las personas que proviene del miedo a que llegue alguien de repente y destruya en un instante lo que lleva tiempo construyéndose.

Por medio de la creación de dioramas, se propició un procedimiento artístico como espacio de reflexión acerca de las consecuencias de dejar el primer hogar a causa de la guerra, como una forma de resistencia al olvido. Los relatos de mi familia como parte fundamental de la investigación tenían fuerzas expresivas contenidas, que hallaron una apertura a través del poder evocador del arte que los volvió tangibles. Esas fuerzas se relacionaban con intentar materializar la casa fantasma de Santa Helena, con los espacios que propiciaban la construcción de vínculos afectivos. También con los momentos que les producían terror, como el intento de toma del corregimiento de Lisboa. A través de la puesta en escena de estos sucesos, tomaban cuerpo esos recuerdos y se establecía un orden de prioridad de lo que era relevante. Para Marisol y Gloria, ver las maquetas de las muñecas que las representaban 
cuando eran niñas era la conexión directa con ese espacio-tiempo con el que se relacionaba el diorama. Por medio de los ambientes creados a partir de las maquetas, se recrearon instantes emotivos de la historia familiar, que se constituyeron en un todo, una cartografía, que daba cuenta de múltiples narraciones entre la vida y la guerra.

El abandono del territorio y del hogar a causa de diferentes modalidades de la violencia con móviles políticos ha sido una constante en la historia de nuestro país. En el contexto rural, las personas, que han construido con el esfuerzo de sus propias manos el espacio que ha de ser su morada, se han visto obligadas en muchos casos a dejarlo todo para preservar la vida. Durante décadas han edificado con esmero cada uno de los elementos que hacen parte de su vida cotidiana, los cuales llevan consigo una carga afectiva que se construye necesariamente con el tiempo. Sin embargo, en un instante, todo se destruye y el territorio deja de brindar protección, y es en ese contexto de destrucción de fuerzas protectoras en que se produce el desarraigo como quiebre intempestivo de vínculos emocionales con el terruño.

\section{REFERENCIAS}

Bachelard, Gaston. 1997. La poética del espacio, 2. ${ }^{a}$ ed. México: Fondo de Cultura Económica.

Deleuze, Gilles y Félix Guattari. 1994. Mil mesetas: capitalismo y esquizofrenia, 2. ${ }^{\text {a }}$ ed. Traducido por José Vásquez Pérez. Valencia: Pre-textos.

Heidegger, Martin. 2001. "Construir, habitar, pensar." En Conferencias y artículos, 2. ${ }^{a}$ ed. Editado por Eustaquio Barjau, 127-142. Barcelona: Ediciones del Serbal.

Pini, Ivonne. 1986. “Luis Ángel Rengifo, grabador". Escala, 2-13.

Rosero, Evelio. 2015. Los ejércitos, 3. ${ }^{a}$ ed. Bogotá: Planeta.

Uribe, María Victoria. 1990. Matar, rematar y contramatar: las masacres de la violencia en el Tolima 1948-1964. Bogotá: Anthropos.

Uribe, María Victoria. 2004. Antropología de la inhumanidad: un ensayo interpretativo sobre el terror en Colombia. Bogotá: Norma.

\section{Cómo citar este artículo:}

Alfaro Buitrago, Estefany. 2017. "Cartografías de migración y desarraigo: percepciones de una casa fantasma a través de la expresión artística". Cuadernos de Música, Artes Visuales y Artes Escénicas 12 (2): 99-124. https://doi.org/10.11144/ Javeriana.mavae12-2.cdmd 